\title{
Archaeological Survey of the Paloma Subdivision, Bexar County, Texas
}

Antonia L. Figueroa

Center for Archeological Research, University of Texas at San Antonio

Follow this and additional works at: https://scholarworks.sfasu.edu/ita

Part of the American Material Culture Commons, Archaeological Anthropology Commons, Environmental Studies Commons, Other American Studies Commons, Other Arts and Humanities Commons, Other History of Art, Architecture, and Archaeology Commons, and the United States History Commons

Tell us how this article helped you.

This Article is brought to you for free and open access by the Center for Regional Heritage Research at SFA ScholarWorks. It has been accepted for inclusion in Index of Texas Archaeology: Open Access Gray Literature from the Lone Star State by an authorized editor of SFA ScholarWorks. For more information, please contact cdsscholarworks@sfasu.edu. 


\section{Archaeological Survey of the Paloma Subdivision, Bexar County, Texas}

Creative Commons License

(c) (i) (8)

This work is licensed under a Creative Commons Attribution-NonCommercial 4.0 International License 


\section{Archaeological Survey of the Paloma Subdivision, Bexar County, Texas}

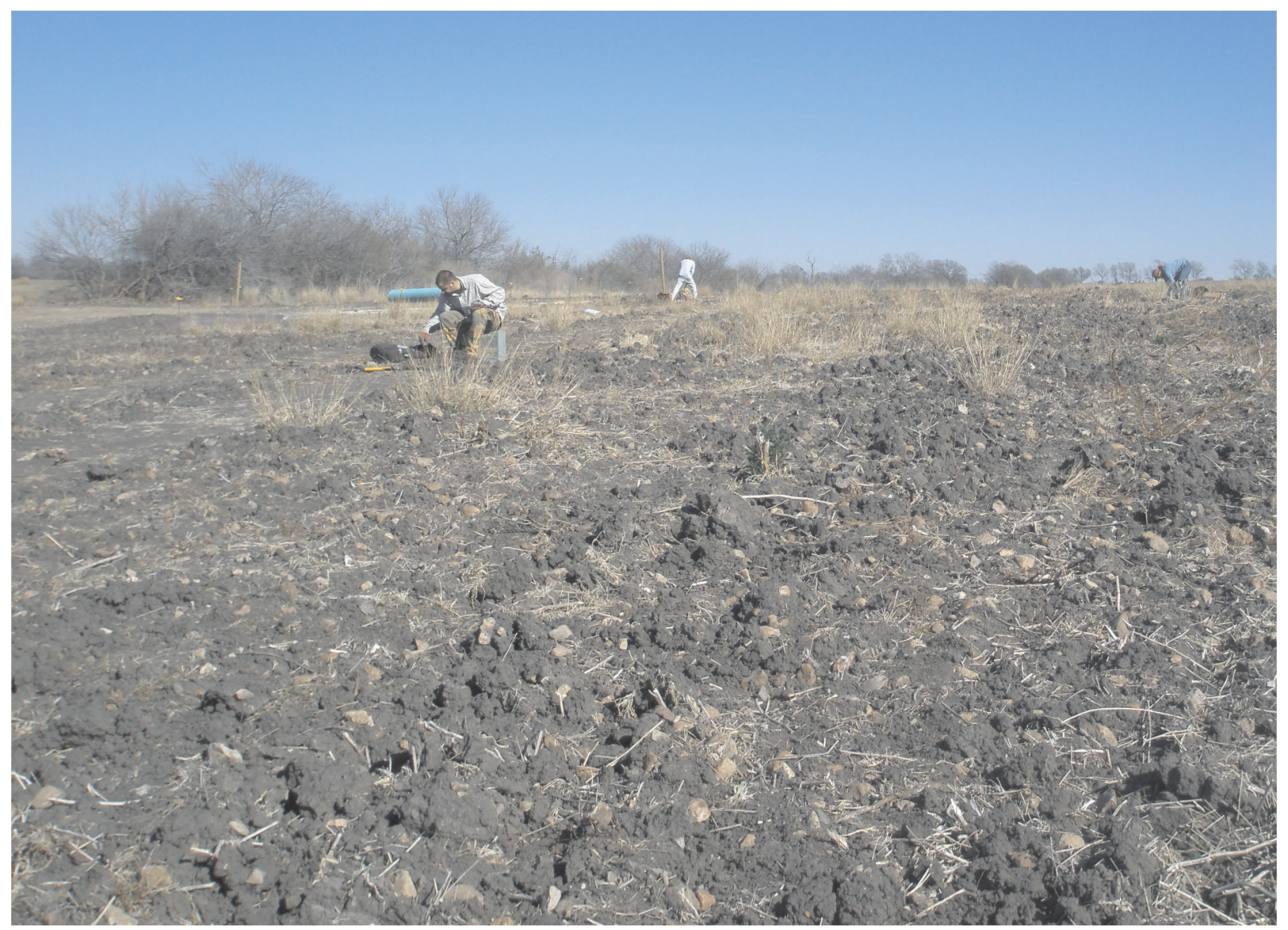

by

Antonia L. Figueroa

Prepared for:

I-10 Investments LTD 4111 Lake Place Lane Austin, Texas 78746

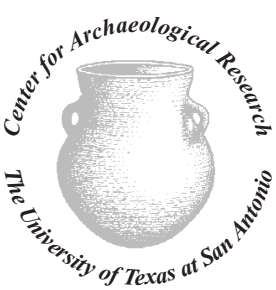

Prepared by:

Center for Archaeological Research The University of Texas at San Antonio Archaeological Report, No. 402 


\title{
Archaeological Survey of the Paloma Subdivision, Bexar County, Texas
}

\author{
by
}

Antonia L. Figueroa

Prepared for:

I-10 Investments LTD

4111 Lake Place Lane Austin, Texas 78746

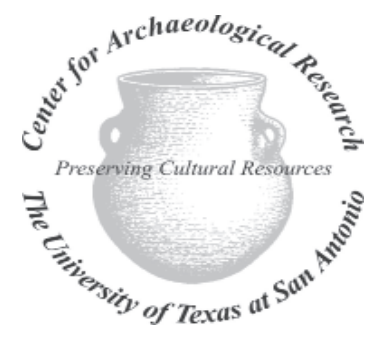

Center for Archaeological Research The University of Texas at San Antonio Archaeological Report No. 402 



\begin{abstract}
:
The Center for Archaeological Research at The University of Texas at San Antonio conducted an archaeological survey for the Paloma Subdivision in Bexar County, Texas. The project area is located in east Bexar County and consisted of approximately 328 acres. During the survey, 85 shovel tests were excavated and sites 41BX1792, 41BX1793, 41BX1794, and 41BX1795 were identified and recorded. Two of the sites possessed prehistoric components (41BX1792 and 41BX1793). A temporal affiliation was not discernable for 41BX1793 but one diagnostic (stem of an Edwards projectile point) was recovered from 41BX1792 dating the site to the Late Prehistoric. 41BX1794 and 41BX1795 were historic farmstead sites with standing structures dating to the early- $20^{\text {th }}$ century to mid- $20^{\text {th }}$ century. None of the sites documented during the project were eligible for listing to the National Register for Historic Places (NRHP) or formal designation as State Archeological Landmarks (SAL). Further work is not recommended on any of archaeological sites recorded during the Paloma Subdivision survey. The San Antonio Historic Preservation Office (HPO) concurred with the recommendations.
\end{abstract}

All materials recovered during the investigations were deeded to the Center for Archaeological Research by the land owner and are curated at the Center, along with all project related documents. 


\section{Table of Contents:}

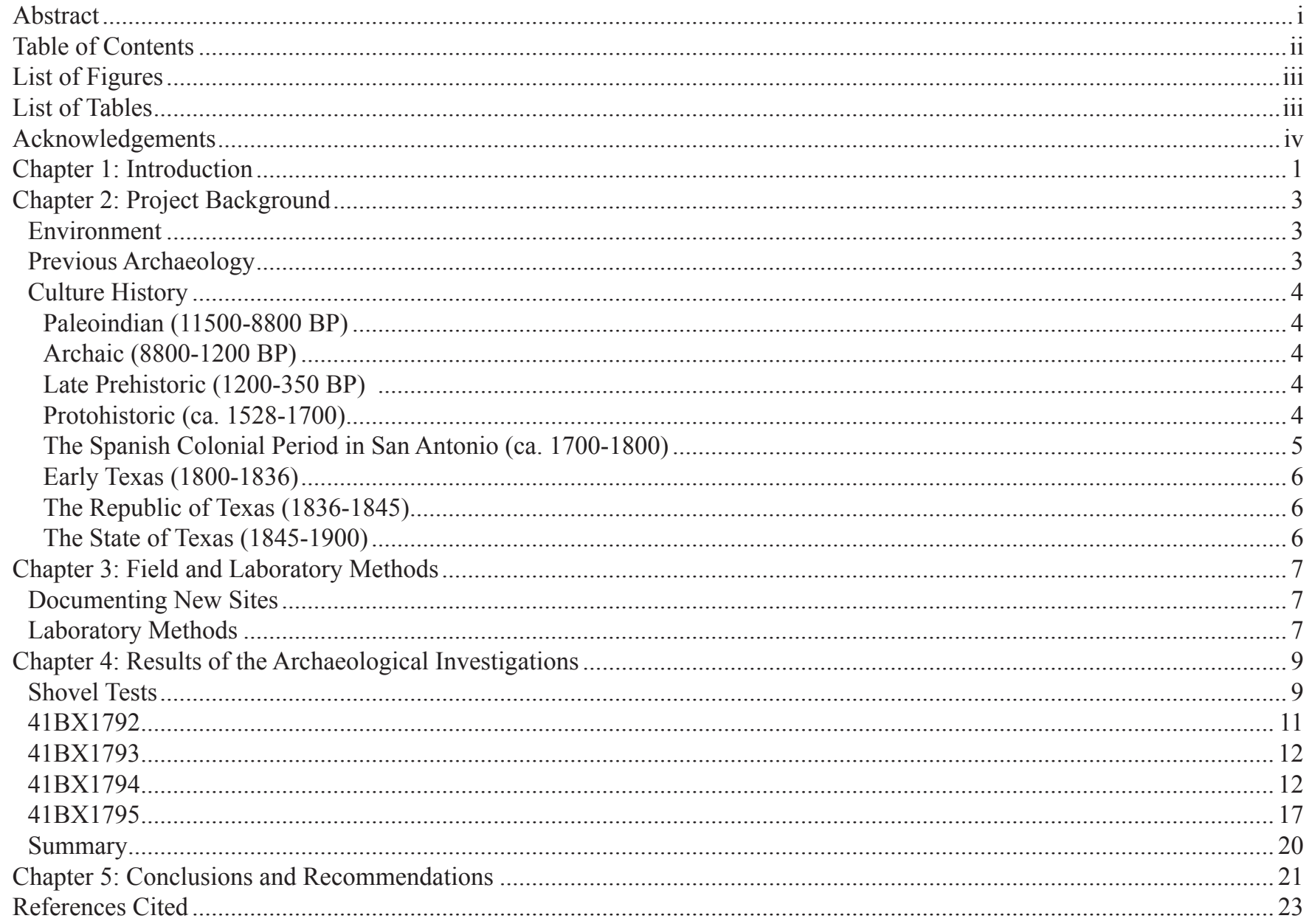




\section{List of Figures:}

Figure 1-1. The location of the project area on the Martinez, Tex., USGS Quadrangle map (2998-134)............................... 1

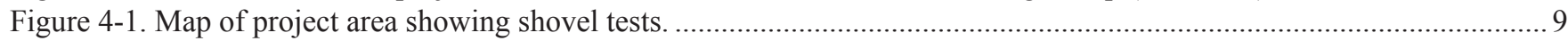

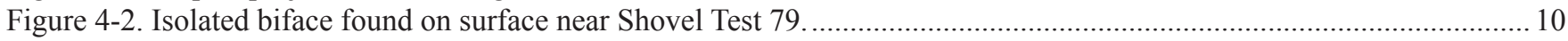

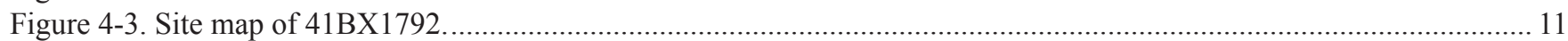

Figure 4-4. Stem of Edwards projectile point recovered from the surface of 41BX1792 ............................................... 12

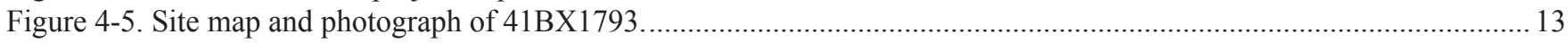

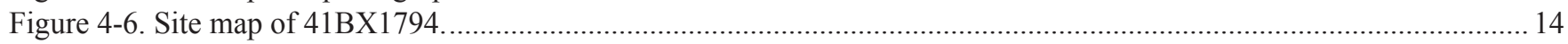

Figure 4-7. The east façade of the main structure at 41BX1794 and fenced construction area (on left). ............................... 15

Figure 4-8. Remnants of a screened in porch off the kitchen on the north-western side of the structure.............................. 15

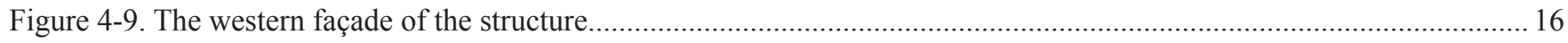

Figure 4-10. The east façade of the main structure at 41BX1794 ............................................................................ 16

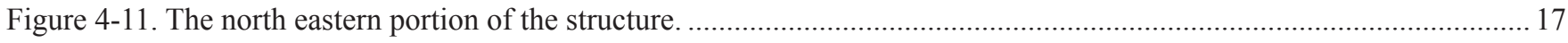

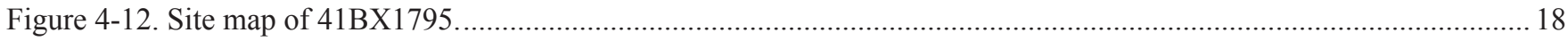

Figure 4-13. The south façade of the main structure at 41BX1795 .............................................................................. 18

Figure 4-14. Outbuilding 9 (garage) and Outbuilding 12 (outhouse) at 41BX1795 (facing east)........................................ 19

Figure 4-15. Outbuildings at 41BX1795: a) barn b) shed and c-d) pens.................................................................... 19

Figure 4-16. Brass compass dated 1942 observed in the main structure of 41BX1795 ...................................................2 20

\section{List of Tables:}

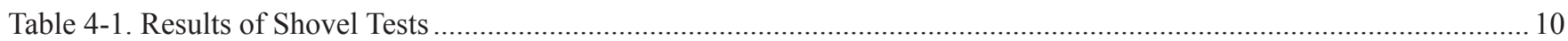

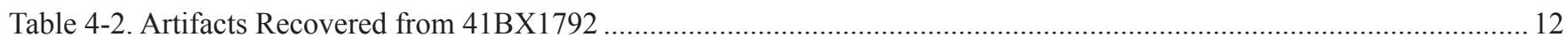

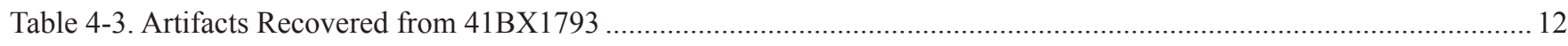

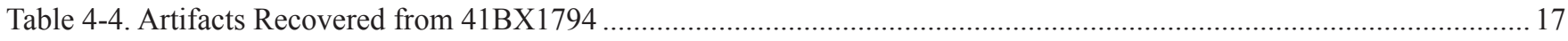




\section{Acknowledgements:}

The pedestrian survey could not have been completed without the field crew that included Cyndi Dickey, Nathan Divito, and Jason Perez. Kay Hindes from the San Antonio Historic Preservation Office provided comments on the draft report. Laboratory duties were conducted by Cathy Stacy under the direction of Marybeth Tomka (laboratory director). I-10 Investments LTD gave us the opportunity to conduct the project. Thanks to Steve Tomka (director) and Raymond Mauldin (assistant director) for their support during the project. Drafting of report figures and the editing of the final report was completed by Bruce Moses. 


\section{Chapter 1: Introduction}

In January 2009, the Center for Archaeological Research of The University of Texas at San Antonio (CAR-UTSA) conducted archaeological investigations for the Paloma Subdivision located in east Bexar County, Texas (Figure 1-1). The CAR was contracted by I-10 Investments LTD to perform a pedestrian survey of the approximately 328 acres. The project area will be impacted by the development of the Paloma Subdivision.

As a result of the archaeological pedestrian survey 85 shovel tests were excavated and four sites were identified and recorded. Two of the sites are prehistoric sites (41BX 1792 and 41BX1793) and one produced a Late Prehistoric diagnostic. 41BX1794 and 41BX1795 are both historic farmstead sites with standing structures that date to the early to mid $20^{\text {th }}$ century. CAR does not recommend the sites for nomination to the National Register of Historic Places (NRHP) or to be formally designated as State Archeological Landmarks (SAL).
The project area is depicted on the Martinez 7.5 Minute Series USGS quadrangle map. The project area, also the Area of Potential Effect (APE), is located in east Bexar County just south of the IH-10 and Loop 1604 intersection and consists of 328 acres. The APE is bound by Green road and old Weichold Road. The majority of the APE has been used for agricultural purposes and has been disturbed by plowing and tilling.

The Project Archaeologist for the project was Antonia L. Figueroa. The project falls under the jurisdiction of San Antonio Historic Preservation Office (HPO) according to the city's Historic Preservation and Design Section of the Unified Development Code (Article 6 35-630 to 35-634) and they required an archaeological survey of the project area according to Archeological Survey Standards for Texas. Disturbance of any site or removal of artifacts from any site within the city without prior review and written clearance by HPO is a violation of the San Antonio Uniform Development Code.

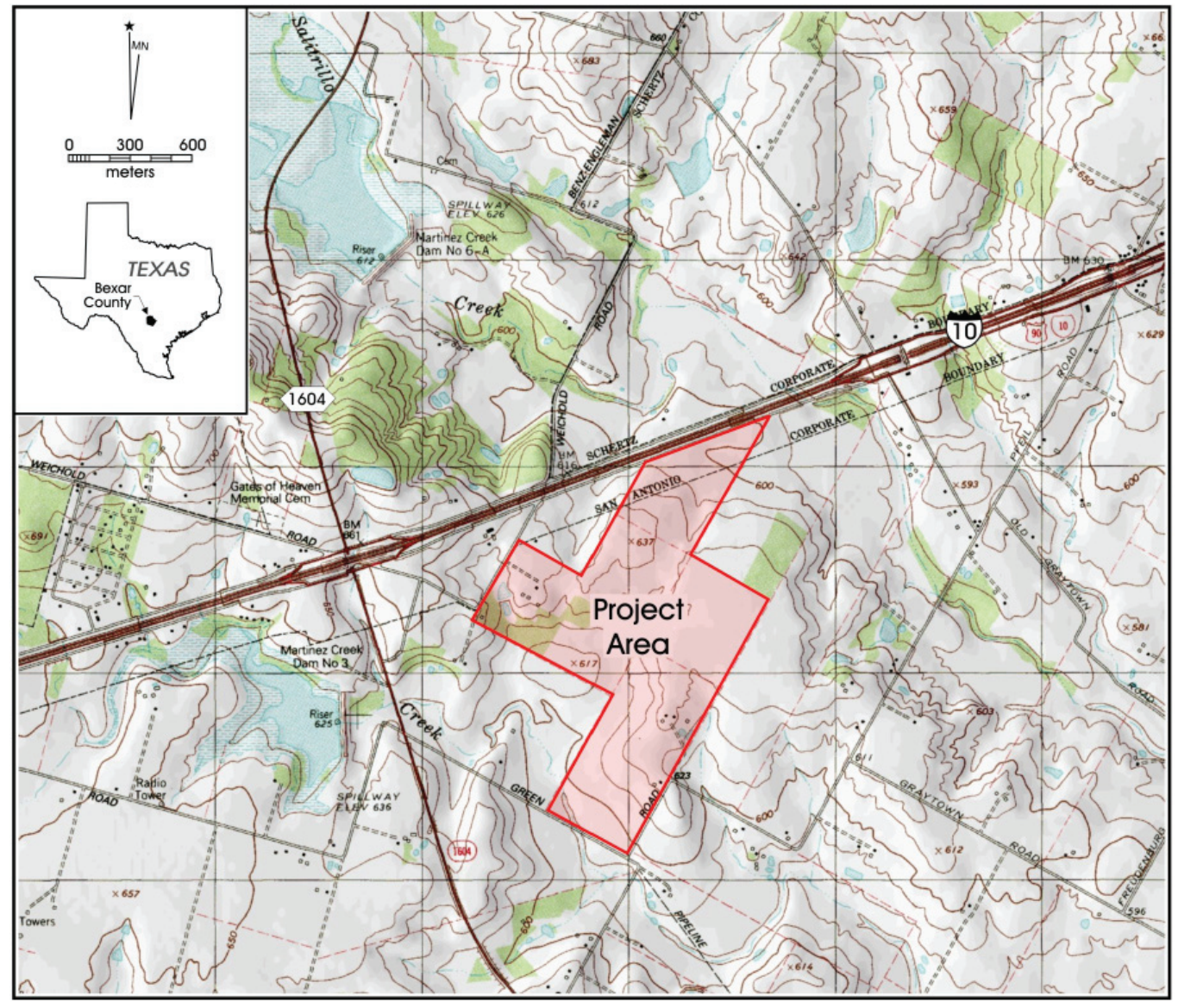

Figure 1-1. The location of the project area on the Martinez, Tex., USGS Quadrangle map (2998-134). 



\section{Chapter 2: Project Background}

In this chapter, the background of the project area is given including the environment, previous archaeology and a culture history of South Texas and the project area. This section begins with a brief discussion on the environment of the project area.

\section{Environment}

The project area is situated south of the Edward's Plateau and below the Balcones Escarpment. Elevations in the project area range from 600 to 650 feet amsl. The nearest natural water source is Escondido Creek that intersects the south eastern portion of the project area. Medina River is approximately three miles to the northeast. Much of the area under the current archaeological investigations has been impacted by agricultural activities. The vegetated portions of the area are dominated by prickly pear, mesquite and white brush.

The project area is located between the South Texas Brush Country and the Blackland Prairies. The climate in this region is typically subtropical with cool winters and hot summers (Taylor et al. 1991). Annual temperatures range from an average low of $37.9^{\circ} \mathrm{F}$ in January to an average high of $95.0^{\circ} \mathrm{F}$ in July (Bomar 1999). Annual average rainfall for San Antonio is 30.98 inches (Bomar 1999).

The soils within for the APE consist of the Houston Black series clayey soils that are deep, dark gray to black, and calcareous. The soils are foundation level and sloping terrain. In the northeastern, south-central and southwestern parts of the county the soils are found in uplands.

\section{Previous Archaeology}

No previous archaeological investigation have been conducted on the project area. Archaeological sites that have been recorded within half a mile of the project area include 41BX1730, 41BX1693, 41BX1318, 41BX1317, 41BX1316, 41BX1731 and 41BX1320.

41BX1730 was recorded in 2007 and is located along Salitrillo Creek (THC 2009). The site contains a prehistoric and historic component and artifacts that are scattered on surface and only extend 10 centimeters below surface $(\mathrm{cmbs})$. Prehistoric materials included burned rock, debitage and lithic tools and are of an unknown temporal affiliation. The historic materials consist of ceramics and metal that date to the late- $19^{\text {th }}$ century to early- $20^{\text {th }}$ century. Further work was not recommended on this site (THC 2009).

41BX1693 is located north-west of the project area and was identified during the Loop 1604 Improvements Project. The site consisted of a surface scatter of burned rock and debitage on and materials within a backhoe trench (Thompson et al. 2008). The site area has been disturbed by plowing. Artifacts were within a mixed context due to plowing. The NRHP eligibly of the site could not be assessed.

41BX1318 is located on Salitrillo Creek and consists of a lithic scatter in an open pasture. Lithic debitage and one core were observed on the site surface while subsurface material consisted of debitage and milk glass. Further work was not recommended and the site has been disturbed by soil deflation, agricultural terracing and low research potential (Kotter 1999:30).

41BX1317 is located along the upper valley margin of Salitrillo Creek. The site is multi-component with at least on of the components dating to the Late Archaic component (Kotter 1999). Lithic tools and debitage were recovered from the site. The site was determined to have low research potential due to the shallowness and disturbance of the cultural deposits (Kotter 1999:22).

41BX1316 consists of a lithic scatter located in a plowed field near Escondido Creek. Cultural material observed on the surface of the site included lithic debitage and tools. Auger testing on the site produced debitage, utilized flakes and one core (Kotter 1999:30). It was recommended that the site be avoided as it may be eligible for designation as a State Archaeological Landmark (SAL), though further testing is required (Kotter 1999: 30).

Site 41BX1731 is a historic period farmstead with a main house and outbuildings (THC 2009). The site is situated along an upland ridge overlooking Escondido Creek. The main house consists of a pier and beam foundation. The buildings and materials on surface date early to mid $20^{\text {th }}$ century.

41BX1320 is a twentieth century (est. 1930s) historic farmstead located west of Loop 1604 just north of the San Antonio corporate boundary, along Escondido Creek. The site was not eligible for the National Register of Historic Places (NRHP) or as a SAL. 


\section{Culture History}

This section summarizes the culture history for the region. Due to the presence of both prehistoric and historic sites in the project area, this discussion begins with the Paleoindian Period and concludes with the historic period of Texas.

\section{Paleoindian (11500-8800 BP)}

The Paleoindian Period corresponds with the oldest documented human presence in Bexar County 11500-8800 B. (Collins 1995). Subsistence patterns during this time focused on large, highly mobile mega fauna but also included the exploitation of small to medium animals. This period is typically divided into early and late segments. The early portion of the period is associated with Clovis and Folsom adaptations. Lithic technology includes fluted Clovis and Folsom projectile points during the early part of this period. In the later portion of the period there were stylistic changes in projectile point technology seen in Dalton, Scottsbluff, and Golondrina traditions. While widespread in geographic range, these types occurred in high densities in the High Plains and Central Texas (Meltzer and Bever 1995). As the climate warmed, megafauna gradually died off, and subsistence patterns shifted.

\section{Archaic (8800-1200 BP)}

This period is subdivided into the Early, Middle and Late subperiods. The subperiods are distinguished by differences in climate conditions, resource availability, subsistence practices and diagnostic projectile points (Collins 1995). Plant gathering appears to have become an important part of subsistence strategies during this period, and was probably even more important during xeric times. Environmental conditions may explain the appearance of burned rock earth ovens during the period. They were used to cook a variety of plant foods that were otherwise inedible, such as the roots of sotol, and yucca (Collins 1995: 383).

In the Early Archaic, (8800-6000 BP) the subsistence shifted from hunting large game to hunting medium and small species and gathering plant foods (Collins 1995). Projectile point styles include Angostura and Early Split Stemmed. Task-specific tools include Clear Fork gouges and Guadalupe and Nueces bifaces (Turner and Hester 1993:246, 256). Early Archaic sites are located along the eastern and southern portions of the Edwards Plateau in areas with reliable water sources (McKinney 1981). Human population densities were relatively low during this subperiod and consisted of small highly mobile bands (Story 1985:39).

The Middle Archaic spans from 6000 to 4000 BP (Collins 1995). Diagnostic projectile points from this period include
Bell, Andice, Taylor, Nolan, and Travis. According to Collins (1995), during the Middle Archaic there was a focus on largegame hunting of bison. However, recent studies suggest an absence of bison during the Middle Archaic (Mauldin and Kemp 2005). Climate was gradually drying as the onset of the Altithermal drought began. Demographic and cultural change likely occurred in response to these hotter and drier conditions.

The last subperiod of the Archaic is the Late Archaic that spans 4000 to 1200 BP (Collins 1995). Dart point diagnostics of the Late Archaic are triangular points with corner notches that include Ensor and Ellis (Turner and Hester 1993:114,122). Other Late Archaic projectile points are Bulverde, Pedernales, Marshall, and Marcos types (Collins 1995). Evidence from the Thunder Valley sinkhole cemetery suggests that territoriality may have established during the Late Archaic, possibly as a result of population increase (Bement 1989). Some researchers state the accumulation of burned rock middens ceased at this time though current research has challenged this notion (Black and Creel 1997; Mauldin et al. 2003).

\section{Late Prehistoric (1200-350 BP)}

The Late Prehistoric period is marked by the Austin and Toyah phases. During the Austin Phase the bow and arrow was introduced. Nickels and Mauldin (2001) suggested at the beginning of this period environmental conditions were warm and dry. More mesic conditions appear to accelerate after 1000 BP Subsistence practices remain relatively unchanged, especially during the Austin Phase. The Austin Phase of the Late Prehistoric may represent the most intensive use of burned rock middens (Black and Creel 1997), and includes diagnostic point types Scallorn and Edwards (Collins 1995; Turner and Hester 1993).

The presence of bone tempered ceramics (Leon Plain) during the Toyah Phase suggests interaction between Central Texas and ceramic producing traditions in East and North Texas (Perttula et al. 1995). Ceramics were in common use in East Texas by $2450 \mathrm{BP}$, but the first Central Texas wares did not appear until ca. 650-700 BP. Other technological traits of this phase include the diagnostic Perdiz point and beveled bifaces. These specialized processing kits are thought to be an adaption to flourishing bison populations by some (Ricklis 1992) and a sign of intensification of declining bison populations by others (Mauldin et al. 2006).

\section{Protohistoric (ca. 1528-1700)}

The Protohistoric Period is a term typically used to describe the transition between the Late Prehistoric and the Colonial 
Period. This period is not well documented archaeologically in Texas. Some researchers (Wade 2003) argue that the Protohistoric Period may coincide with the end of the Late Prehistoric Toyah Interval, spanning the period of A.D. $1250 / 1300$ to A.D. $1600 / 1650$ (Hester 1995). For the purposes of this report, we define the period as beginning with the Early Spanish explorations in Texas (ca. 1528) and ending with the establishment of a strong Spanish presence in the region in the late 1600 s and early 1700 s.

During this period, there was intermittent contact between the native groups and Spanish explorers. It was a time before the Spanish economy significantly impacted the indigenous groups in the area. A number of encounters between the indigenous communities and Europeans were recorded during this period, including those of Cabeza de Vaca (1528-1536) and the French settlement established by Rene Robert Cavelier, Sieur de La Salle (1685-1689). The Spanish sent General Alfonso de Leon into the area in 1689, and in 1691 the area of present-day San Antonio was first visited by Domingo de Teran.

Archaeologically, the time period is poorly documented but has been identified at several sites in south Texas counties (e.g., Hall et al. 1986; Inman et al. 1998; Mauldin et al. 2004). A problematic issue concerning this time period is that there is not a clear material culture associated with the period. Therefore, it is difficult to document this time period archaeologically without absolute dates. Sites that have been deemed as "Protohistoric" may have Late Prehistoric and/or Historic artifacts associated with them, and in several cases radiocarbon dates confirm their Protohistoric designation (Mauldin et al. 2004).

\section{The Spanish Colonial Period in San Antonio (ca. 1700-1800)}

The first Spanish presidios in North America began to appear in 1565 with the establishment of San Agustin on the Atlantic coast of Florida (Moorhead 1991:27). The establishment of the presidios was mainly due to the encroachment of European powers, predominantly the French (Moorhead 1991:27). The first attempt to have an established Spanish presence in Texas was the founding of Mission San Francisco de los Tejas, established in 1690 near Nacogdoches, and Santismo Nombre de Maria, built on the banks of the Neches River in that same year. Both attempts were short-lived, and by 1693 , both were abandoned (Fox and Cox 2000). The founding of Mission San Juan in 1700 along the Rio Grande marked the beginning of an established Spanish presence in the region (Weddle 1968).

In 1718, Don Martín del Alarcón established Presidio San Antonio de Béxar and Mission San Antonio de Valero near the headwaters of San Pedro Creek (Chipman 1992:14; Hoffman 1937). In 1722, Marqués de Aguayo relocated the villa and presidio to their final locations on the west side of the San Antonio River. The presidio and the villa were named after the Duke of Béjar, the elder brother of the Viceroy (Buerkle 1976:50). The purpose of the San Antonio de Bexar presidio was not only to protect the mission, town, farms and ranches, but also serve as a way-station between Mexico and the East Texas settlements. After a four-month stay in East Texas, Alarcón returned to San Antonio where he faced challenges and problems with the missionary fathers (Buerkle 1976:51). After his request for additional soldiers, funds, and supplies was denied, Alarcón resigned from his position in 1719 (Buerkle 1976:51).

In 1719, Marqués de San Miguel de Aguayo became the governor and captain general of Coahuila and Texas. He led an expedition into Texas to return Spanish presence to the frontier. Aguayo and his troops re-supplied in San Antonio before returning to East Texas for eight months. While in East Texas, Aguayo re-established the presidios and installed new missions (Buerkle 1976:52). Upon his return to San Antonio, he found that the granary at the presidio, along with several of the soldiers' jacales, had been destroyed by fire. Aguayo ordered that a new presidio be built of adobe. Harsh weather delayed the progress of the new presidio and it was apparently never completed. The construction never "progressed beyond two towers, a surrounding wall and some scattered wooden or jacal structures" (Buckley 1991).

In 1720, Mission San José y San Miguel de Aguayo was established in the area, followed by the missions Nuestra Señora de la Purisima Concepción de los Hasinai, San Francisco de Espada and San Juan Capistrano. The establishment of Villa de San Fernando occurred in 1731. The settlement was to be home to Canary Islanders (Isleños). The villa became the first civilian settlement of Texas.

The Seven Year War began in 1756 and changed the dynamics of Spanish colonialism in Texas. The British replaced the French as a major threat to Spanish presence, and Spain had to fortify its settlements in Louisiana and California against indigenous groups. As a result of this shift in focus, East Texas settlements began to deteriorate and populations were relocated to San Antonio. During the later part of the eighteenth century, the missions in San Antonio began to decline due to a shortage of priests and a decline in population and workers to maintain the agricultural fields.

In 1790, Manuel Silva, under the College of Zacatecas, recommended that Mission San Antonio de Valero be secularized. Furthermore, of the four remaining missions only two were still functioning. By 1794, Mission San 
Antonio de Valero was secularized and the surrounding lands distributed to the remaining Mission Indians and other individuals.

\section{Early Texas (1800-1836)}

In 1802 the Compania Volante de San Carlos del Alamo de Parras from Coahuila occupied the Presidio de San Antonio de Béxar (Cox 2005). The soldiers were assigned quarters in the abandoned Mission San Antonio. It was at this time that the former mission became known as the Alamo.

Discontent with New Spain in the northern provinces led to the Hidalgo revolt in 1810. Mexico became independent from Spain in 1821. The 1824 constitution merged Texas and Coahuila into one state, with San Antonio de Béxar as a separate department (Fox et al. 1997).

Spain's attempt to regain control of Mexico in 1829 failed. Stephen F. Austin asked San Antonio to provide support for his efforts to make Texas a separate entity in 1833. The same year, Santa Ana became the President of Mexico.

General Cós and his troops were pushed out of San Antonio under Ben Milam in December of 1835. The Mexican army arrived in San Antonio in February 1836 and the Alamo and Texan troops were assaulted and defeated in early March of 1836. Later that year, Santa Ana was finally defeated and caught at the Battle of San Jacinto (Fox et al. 1997).

\section{The Republic of Texas (1836-1845)}

Sam Houston was inaugurated as the first president of the Republic of Texas in 1836. The Texas Congress set the boundaries for the newly formed republic as the Rio Grande in the south and Louisiana eastern boundary (Nance 2004). The population of San Antonio increased due to immigration. The new city council of San Antonio elected John W. Smith as mayor in 1837.

Mexico refused to recognize the independence of Texas and a formal state of war continued. General Rafael Vasquez, with 700 soldiers, attempted to take over San Antonio and the unprepared Texan force retreated to present-day Seguin. In 1842, a friend of Santa Ana, General Adrian Woll, captured San Antonio, and this time the Texans resisted. Finally, in 1844 a truce was called between Mexico and Texas (Fox et al. 1997).

\section{The State of Texas (1845-1900)}

On December 29, 1845, the United States Congress approved the Texas State Constitution and Texas was admitted as a state. This act, coupled with the failure to agree on the Rio Grande as a boundary and on the sale of California to the United States, resulted in the war between the United States and Mexico (1846-1848). In early 1846, General Zachary Taylor advanced to the Rio Grande, occupying land that the Mexican government viewed as its own, and war was declared in May of that year. After a series of battles, the United States military occupied Mexico City in August of 1847. In May of 1848, the ratification of the Treaty of Guadalupe Hidalgo by the Mexican government signaled the end of hostilities, established the Rio Grande as a boundary, and gave the United States present-day Arizona, California, New Mexico, Texas and parts of Colorado, Nevada and Utah in exchange for $\$ 15$ million. United States troops left Mexico in June of that same year (Bauer 1974; Wallace 1965).

With the boundaries of Texas now established, the new state soon found itself embroiled in controversy over its position on slavery. The majority of the population within the state was derived from the south, and while ranching and subsistence farming were probably the major economic activities, cottonbased agriculture was the major cash crop. In 1846, Texas had more than 30,000 black slaves, many associated with cotton production. At the breakout of the Civil War, thousands of Texans fought on both sides, with the effects of the war seen throughout Texas, including shortages of commodities in San Antonio. On June 19, 1865, General Gordon Granger arrived in Galveston with Union forces, signaling the end of the Civil War (Fox et al. 1997).

In February 1877, the Galveston, Harrisburg and San Antonio Railroad arrived in the area. With the arrival of the railroad, commercial elements were introduced into the area for the first time (Fox et al. 1997). A growth in business was created near the depot, including stores and saloons. City waterworks also commenced during this time and the city continued to expand. At the beginning of the twentieth century, the population of San Antonio was just over 53,000 (Fox et al. 1997).

While most of the historic period settlement conducted into San Antonio proper, during the $19^{\text {th }}$ and early $20^{\text {th }}$ centuries many ranches and farmsteads were established on the outskirts thoughout Bexar County. The previous summary suggests that the cultural resources found within the project area may consist of prehistoric sites ranging in age from Paleoindian to Late Prehistoric as well as farmsteads dating to the late $19^{\text {th }}$ and early $20^{\text {th }}$ centuries. 


\section{Chapter 3: Field and Laboratory Methods}

For this archaeological project measuring 328 acres, approximately one shovel test was excavated every 4 acres. The project area was traversed by the CAR field crew on transects spaced 30 meters apart. All shovel tests were 30 $\mathrm{cm}$ in diameter and excavated to a depth of 60 centimeters below surface (cmbs) in 10-cm levels. Soils were screened through .25 in. mesh. CAR crews recorded the location of all excavated shovel tests with a Trimble GPS unit and the project archaeologist plotted their locations on an aerial map of the project area. A shovel test form was completed for each unit and included observations of soil texture and color, artifact counts and depth, excavation depth of the shovel test, and other surveyor notes.

Shovel tests that contained cultural material at least 50 years old and therefore represent either historic or prehistoric components were identified as positive shovel tests. Upon excavation of a positive shovel test, additional shovel tests were excavated at decreased intervals $15 \mathrm{~m}$ in each cardinal direction from the original test in order to determine whether a site was present and to define the site boundaries if it met the site definition (discussed below). Additional shovel tests were excavated until no cultural materials were recovered.

All artifacts were collected from the field, analyzed, and processed in the CAR laboratory with photographs and paperwork generated during this project for permanent curation.

\section{Documenting New Sites}

During the archaeological survey, new sites were defined as follows: 1) locations with at least five artifacts within a $30 \mathrm{~m}^{2}$ area or; 2) a location containing a single cultural feature such as a hearth, either on surface or exposed in a shovel test or; 3 ) a location with a positive shovel test containing at least three artifacts within a given $10-\mathrm{cm}$ level or; 4) a location with a positive shovel test containing at least five total artifacts or; 5) two positive shovel tests located within $30 \mathrm{~m}$ of each other. All surface artifacts or positive shovel tests that do not meet the site definitions presented above were classified as isolated finds.

In addition, sketch maps showing site boundaries, datum locations, shovel tests, collected items, archaeological features and physical features of the landscape were drawn. The site boundary, datum, shovel tests, and other landmarks within or near the site such as standing structures, creeks, or fences were collected with a GPS. Site forms were prepared for all newly documented sites using standard forms and sites were recorded in the Texas Archeological Sites Atlas database and a trinomial was obtained.

\section{Laboratory Methods}

All cultural material collected during the survey was prepared in accordance with federal regulation 36 CFR part 79 and in accordance with current guidelines of the Center for Archaeological Research. Artifacts were processed in the CAR laboratory where they were washed, air-dried, and stored in archival-quality bags. Artifacts were sorted into appropriate analytical categories. Acid-free labels were placed in all artifact bags. Each label displayed provenience information and a corresponding lot number laser printed or written in pencil. Artifacts were separated by class and stored in acid-free boxes identified with standard labels. The data was entered into a Microsoft Access database. All artifacts were permanently curated at CAR. Field notes, forms, and hard copies of photographs were placed in labeled archival folders. All field forms were completed in pencil. Documents and forms were printed on acid-free paper and any soiled forms were placed in archival-quality page protectors. A copy of the final report in Adobe Acrobat ${ }^{\circledR}$ file format and all digital material pertaining to the project, including photographs, were burned onto a $\mathrm{CD}$ and permanently curated with the field notes and documents at the Center for Archaeological Research. 



\section{Chapter 4: Results of the Archaeological Investigations}

CAR conducted a pedestrian survey of a 328 acre tract of land associated with the proposed Paloma Subdivision. During the survey, 85 shovel tests were excavated and four sites were identified and documented (Figure 4-1). Two of the newly recorded sites (41BX1792 and 41BX1793) contained evidence of prehistoric materials that consisted of burned rock, lithic debitage and tools. Large portions of the prehistoric sites 41BX1792 and 41BX1793 have been disturbed by plowing and CAR does not recommend them for listing to the NRHP or formal SAL designation. Sites 41BX1794 and 41BX1795 are historic farmstead sites with standing structures that included dwellings and outbuildings that date to the early- $20^{\text {th }}$ to mid- $20^{\text {th }}$ century. Due to the poor integrity of the structures, and the low density of cultural material encountered in associated shovel tests, CAR does not recommend the sites for listing to the NRHP or SAL status. Texsite forms were submitted to the Texas Archeological Research Laboratory (TARL) in Austin and trinomial numbers were secured. The remainder of this chapter presents the results for the archaeological survey of the APE.

\section{Shovel Tests}

Shovel tests were disturbed along transects spaced 30 meters apart. Only approximately eight acres, in the northwestern portion of the project area within the vicinity of 41BX1795, has not been disturbed by plowing. Soils encountered in shovel tests consisted mainly of dark grayish brown clay. Shovel tests excavated in plowed areas revealed 30 to 40 centimeters $(\mathrm{cm})$ of plow zone with $10-15 \%$ cobble inclusions.

Out of the 85 excavated shovel tests $24(28 \%)$ were positive for cultural material (Table 4-1). Twenty of the positive shovel tests were included in sites 41BX1792, 41BX1793, 41BX1794 and 41BX1795. The remaining four positive shovel tests were identified as isolated finds (ST 17, 35, 68 and 80). Shovel Test 17 was positive for one piece of debitage in Level 6. Shovel Tests 65, 66 and 67 were excavated 15 meters in the cardinal directions from Shovel Test 17 and were negative for cultural material. It was not possible to shovel test to the east of Shovel Test 17 due to disturbance caused by clearing of the area.

Shovel Test 35 is located in the northern portion of the project area. Cultural materials recovered from the shovel test included debitage from Levels $3(\mathrm{n}=2)$ and $6(\mathrm{n}=1)$. Four shovel tests were excavated 15 meters $(\mathrm{m})$ in the cardinal directions from ST 35 (Shovel Tests 76, 77,

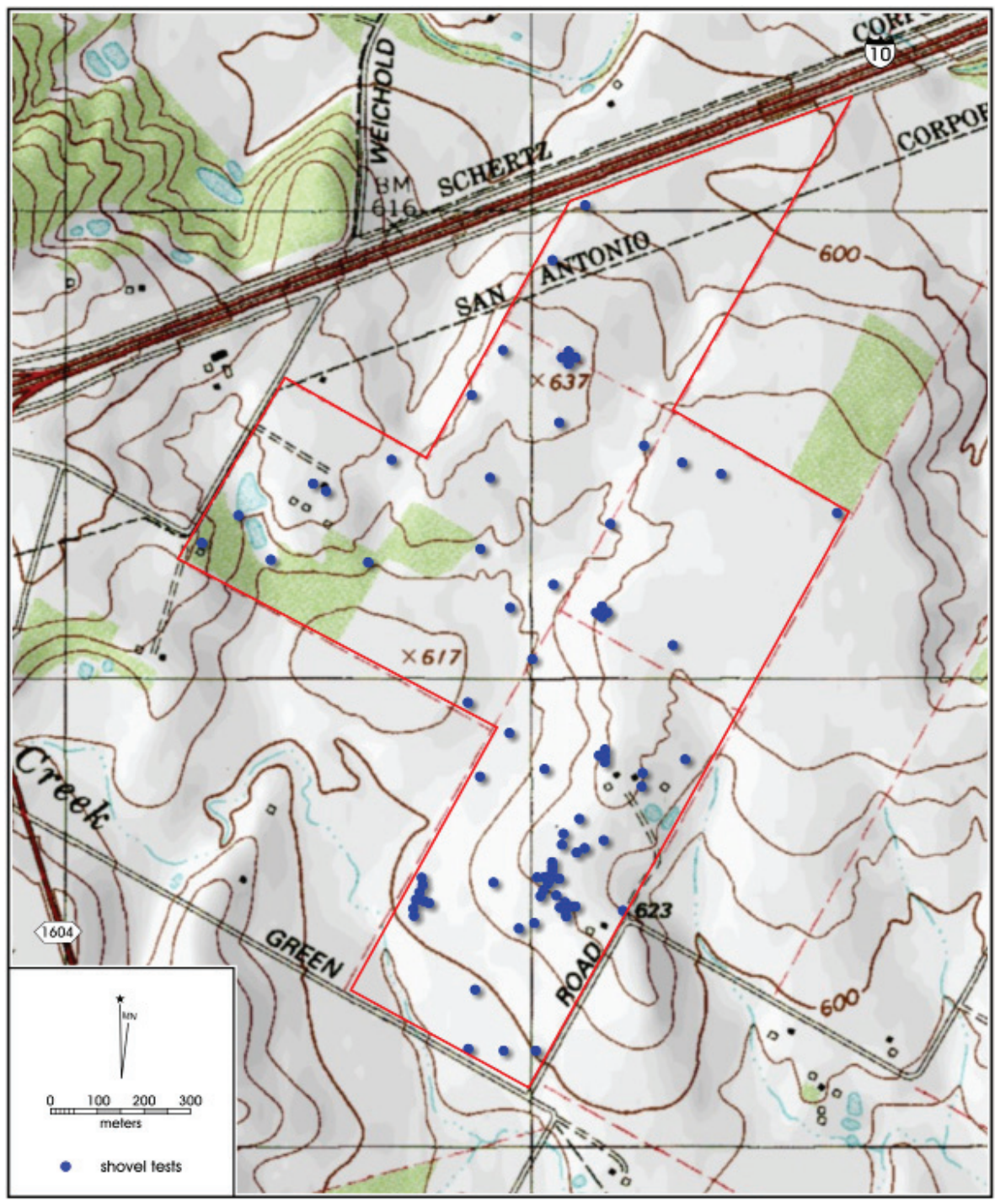

Figure 4-1. Map of project area showing shovel tests. 
Table 4-1. Results of Shovel Tests

\begin{tabular}{|c|c|c|}
\hline Site & $\begin{array}{c}\text { Shovel } \\
\text { Test }\end{array}$ & Results \\
\hline$n / a$ & 1 & negative \\
\hline $\mathrm{n} / \mathrm{a}$ & 2 & negative \\
\hline $\mathrm{n} / \mathrm{a}$ & 3 & negative \\
\hline $\mathrm{n} / \mathrm{a}$ & 4 & negative \\
\hline 41BX1793 & 5 & positive \\
\hline $\mathrm{n} / \mathrm{a}$ & 6 & negative \\
\hline$n / a$ & 7 & negative \\
\hline $\mathrm{n} / \mathrm{a}$ & 8 & negative \\
\hline 41BX1792 & 9 & positive \\
\hline 41BX1792 & 10 & positive \\
\hline $\mathrm{n} / \mathrm{a}$ & 11 & negative \\
\hline $\mathrm{n} / \mathrm{a}$ & 13 & negative \\
\hline $\mathrm{n} / \mathrm{a}$ & 14 & negative \\
\hline $\mathrm{n} / \mathrm{a}$ & 15 & negative \\
\hline $\mathrm{n} / \mathrm{a}$ & 16 & negative \\
\hline isolated find & 17 & positive \\
\hline $\mathrm{n} / \mathrm{a}$ & 18 & negative \\
\hline $\mathrm{n} / \mathrm{a}$ & 19 & negative \\
\hline $\mathrm{n} / \mathrm{a}$ & 20 & negative \\
\hline $\mathrm{n} / \mathrm{a}$ & 21 & negative \\
\hline $\mathrm{n} / \mathrm{a}$ & 22 & negative \\
\hline $\mathrm{n} / \mathrm{a}$ & 23 & negative \\
\hline $\mathrm{n} / \mathrm{a}$ & 24 & negative \\
\hline $\mathrm{n} / \mathrm{a}$ & 25 & negative \\
\hline $\mathrm{n} / \mathrm{a}$ & 26 & negative \\
\hline $\mathrm{n} / \mathrm{a}$ & 27 & negative \\
\hline $\mathrm{n} / \mathrm{a}$ & 28 & negative \\
\hline
\end{tabular}

\begin{tabular}{|c|c|c|}
\hline Site & $\begin{array}{c}\text { Shovel } \\
\text { Test }\end{array}$ & Results \\
\hline$n / a$ & 29 & negative \\
\hline $\mathrm{n} / \mathrm{a}$ & 30 & negative \\
\hline$n / a$ & 31 & negative \\
\hline $\mathrm{n} / \mathrm{a}$ & 32 & negative \\
\hline $\mathrm{n} / \mathrm{a}$ & 33 & negative \\
\hline$n / a$ & 34 & negative \\
\hline isolated find & 35 & positive \\
\hline$n / a$ & 36 & negative \\
\hline$n / a$ & 37 & negative \\
\hline$n / a$ & 38 & negative \\
\hline 41BX1792 & 39 & positive \\
\hline 41BX1792 & 40 & positive \\
\hline $\mathrm{n} / \mathrm{a}$ & 41 & negative \\
\hline$n / a$ & 42 & negative \\
\hline 41BX1793 & 43 & positive \\
\hline 41BX1793 & 44 & positive \\
\hline 41BX1793 & 45 & positive \\
\hline n/a & 46 & negative \\
\hline 41BX1793 & 47 & positive \\
\hline 41BX1793 & 48 & positive \\
\hline$n / a$ & 49 & negative \\
\hline $\mathrm{n} / \mathrm{a}$ & 50 & negative \\
\hline 41BX1792 & 51 & positive \\
\hline 41BX1792 & 52 & positive \\
\hline 41BX1792 & 53 & positive \\
\hline $\mathrm{n} / \mathrm{a}$ & 54 & negative \\
\hline 41BX1792 & 55 & positive \\
\hline
\end{tabular}

\begin{tabular}{|c|c|c|}
\hline Site & $\begin{array}{c}\text { Shovel } \\
\text { Test }\end{array}$ & Results \\
\hline $\mathrm{n} / \mathrm{a}$ & 56 & negative \\
\hline 41BX1792 & 57 & positive \\
\hline $\mathrm{n} / \mathrm{a}$ & 58 & negative \\
\hline 41BX1792 & 59 & positive \\
\hline $\mathrm{n} / \mathrm{a}$ & 60 & negative \\
\hline 41BX1792 & 61 & positive \\
\hline 41BX1792 & 62 & positive \\
\hline 41BX1793 & 63 & positive \\
\hline 41BX1793 & 64 & positive \\
\hline $\mathrm{n} / \mathrm{a}$ & 65 & negative \\
\hline $\mathrm{n} / \mathrm{a}$ & 66 & negative \\
\hline $\mathrm{n} / \mathrm{a}$ & 67 & negative \\
\hline isolated find & 68 & positive \\
\hline $\mathrm{n} / \mathrm{a}$ & 69 & negative \\
\hline $\mathrm{n} / \mathrm{a}$ & 70 & negative \\
\hline $\mathrm{n} / \mathrm{a}$ & 71 & negative \\
\hline $\mathrm{n} / \mathrm{a}$ & 72 & negative \\
\hline $\mathrm{n} / \mathrm{a}$ & 73 & negative \\
\hline $\mathrm{n} / \mathrm{a}$ & 74 & negative \\
\hline $\mathrm{n} / \mathrm{a}$ & 75 & negative \\
\hline $\mathrm{n} / \mathrm{a}$ & 76 & negative \\
\hline $\mathrm{n} / \mathrm{a}$ & 77 & negative \\
\hline $\mathrm{n} / \mathrm{a}$ & 78 & negative \\
\hline$n / a$ & 79 & negative \\
\hline isolated find & 80 & positive \\
\hline
\end{tabular}

78 and 79) and were negative of cultural material. A single biface was located on the surface near Shovel Test 79. The biface was not collected and was identified as an isolated find (Figure 4-2).

Shovel Test 68 was excavated in the northeastern portion of the project area and contained a single piece of lithic debitage in Level 2. Shovel Tests 70, 71,72 and 73 were excavated 15 meters from ST 68 in the cardinal directions. The four shovel tests were negative for cultural material.

ST 80 was excavated in the vicinity of a piece of debitage noted on surface. The shovel test was negative for cultural material, expect the artifact was classified as an isolated find.

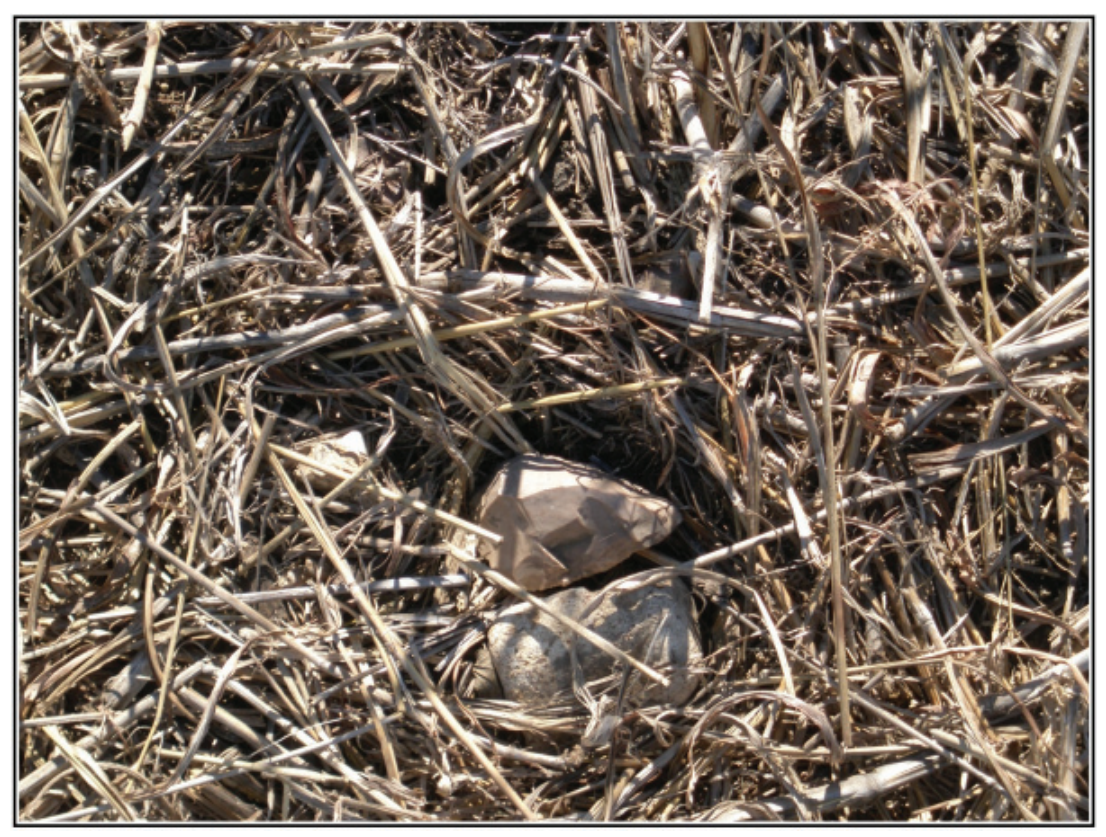

Figure 4-2. Isolated biface found on surface near Shovel Test 79. 


\section{BX1792}

41BX1792 was located in the south-eastern portion of the project area. The site is located in two agricultural fields that are dissected by a tree line (Figure 4-3). The two fields have subjected to extensive plowing activities and the western field more recently. Cultural material in the form of burned rock, lithic tools and debitage is scattered on the surface of the site that measures approximately $13,100 \mathrm{~m}^{2}$.

Lithic tools scattered on the surface consist of two bifaces (not collected) and the base of an Edwards projectile point that dates to the Late Prehistoric Period (Figure 4-4 scan). Thirteen out of 21 shovel tests were positive for cultural material (Table 4-2). The majority of material consisted of burned rock $(n=62)$ and the pieces were less than $2 \mathrm{~cm}$ in size and did not appear to be associated with any features.

Eight pieces of debitage were recovered. The majority $(89 \%)$ of cultural material was recovered from the first 40 $\mathrm{cm}$ of the shovel tests which showed evidence of plowing disturbance. No features were documented although the small pieces of fire-cracked rock does suggest that they may have been present before plowing. Due to the disturbance caused by plowing and the lack of intact deposits CAR recommends that the site is not eligible for NRHP nomination or formal listing as an SAL. Further work is not recommended on the site.

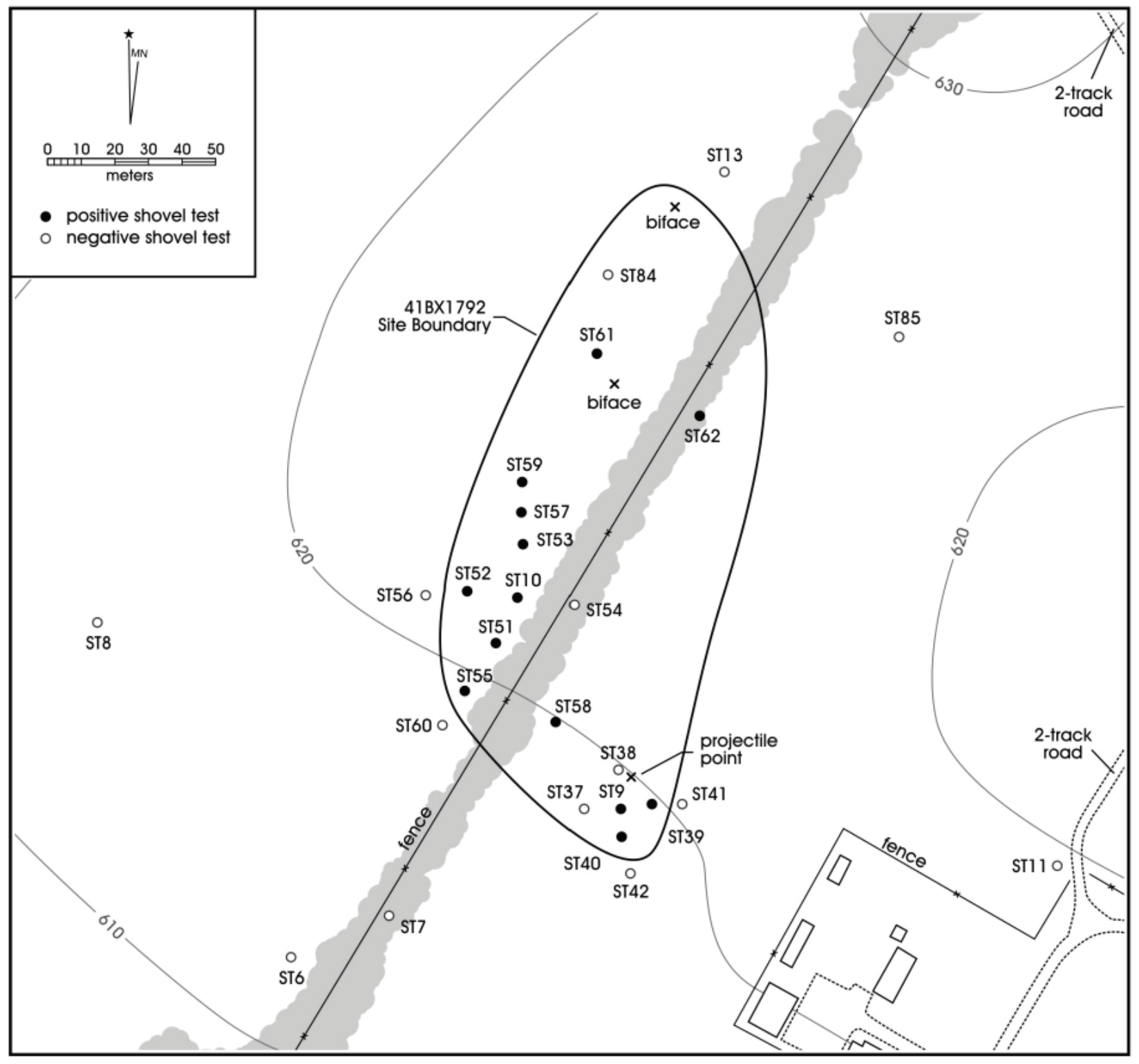

Figure 4-3. Site map of 41BX1792. 

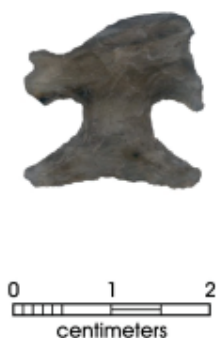

Figure 4-4. Stem of Edwards projectile point recovered from the surface of $41 B X 1792$.

Table 4-2. Artifacts Recovered from 41BX1792

\begin{tabular}{|c|c|c|c|c|c|}
\hline $\begin{array}{c}\text { Shovel } \\
\text { Test }\end{array}$ & Level & $\begin{array}{c}\text { Burned } \\
\text { rock }\end{array}$ & Debitage & $\begin{array}{l}\text { Lithic tools } \\
\text { and cores }\end{array}$ & $\begin{array}{c}\text { Grand } \\
\text { Total }\end{array}$ \\
\hline \multirow{2}{*}{9} & 1 & 2 & - & - & 2 \\
\hline & 3 & 1 & - & - & 1 \\
\hline \multirow{3}{*}{10} & 4 & 6 & - & - & 6 \\
\hline & 5 & 5 & - & - & 5 \\
\hline & 6 & 1 & - & - & 1 \\
\hline 39 & 3 & 3 & - & - & 3 \\
\hline 40 & 1 & 1 & - & - & 1 \\
\hline 5 & 6 & - & 1 & - & 1 \\
\hline 51 & 2 & 2 & 1 & - & 3 \\
\hline \multirow{4}{*}{52} & 1 & 2 & - & - & 2 \\
\hline & 2 & 3 & 2 & - & 5 \\
\hline & 3 & 4 & - & - & 4 \\
\hline & 4 & 2 & - & - & 2 \\
\hline \multirow{4}{*}{53} & 1 & 2 & - & - & 2 \\
\hline & 2 & 4 & - & - & 4 \\
\hline & 3 & 3 & - & - & 3 \\
\hline & 4 & - & 1 & - & 1 \\
\hline 55 & 4 & 1 & - & - & 1 \\
\hline \multirow{3}{*}{57} & 1 & 4 & - & - & 4 \\
\hline & 2 & 3 & 1 & - & 4 \\
\hline & 3 & 3 & - & - & 3 \\
\hline \multirow{4}{*}{59} & 1 & 2 & 1 & - & 3 \\
\hline & 2 & 2 & - & - & 2 \\
\hline & 3 & 2 & - & - & 2 \\
\hline & 4 & 2 & - & - & 2 \\
\hline 61 & 3 & 2 & - & - & 2 \\
\hline 62 & 6 & - & 1 & - & 1 \\
\hline surface & 0 & - & - & 1 & 1 \\
\hline \multicolumn{2}{|c|}{ Grand Total } & 62 & 8 & 0 & 71 \\
\hline
\end{tabular}

\section{BX1793}

$41 \mathrm{BX} 1793$ is located in the southwestern portion of the project area along an ephemeral portion of Escondido Creek and occupies 2,392 $\mathrm{m}^{2}$ (Figure 4-5). A fence line (and also the APE limits) bounds the site to the west. Extensive plowing has occurred in the environs of the site. Nine shovel tests were excavated on the site that produced burned rock and debitage (Table 4-3). Cultural material was not observed on surface but was present most frequently in shovel test Levels 1 through 4 that had been disturbed by plowing. The majority of cultural material consisted of burned rock $(n=62)$, that were small pieces $(<2 \mathrm{~cm})$ and that may have been associated with any features before plowing occurred. Due to the disturbance to the site by plowing, lack of intact deposits and the low density of artifacts the CAR does not recommend the site eligible for nomination to the NRHP or as SAL status. Further work on the site is not recommended.

Table 4-3. Artifacts Recovered from 41BX1793

\begin{tabular}{|c|c|c|c|c|}
\hline $\begin{array}{c}\text { Shovel } \\
\text { Test }\end{array}$ & Level & $\begin{array}{c}\text { Burned } \\
\text { rock }\end{array}$ & Debitage & $\begin{array}{c}\text { Grand } \\
\text { Total }\end{array}$ \\
\hline 5 & 6 & 0 & 1 & 1 \\
\hline \multirow{3}{*}{24} & 1 & 1 & - & 1 \\
\hline & 2 & 1 & - & 1 \\
\hline & 5 & 1 & - & 1 \\
\hline \multirow{6}{*}{43} & 1 & 1 & - & 1 \\
\hline & 2 & - & - & 0 \\
\hline & 3 & 1 & - & 1 \\
\hline & 4 & 1 & 1 & 2 \\
\hline & 5 & 1 & 1 & 2 \\
\hline & 6 & 1 & - & 1 \\
\hline \multirow{2}{*}{44} & 1 & 1 & 1 & 2 \\
\hline & 2 & 1 & - & 1 \\
\hline \multirow{6}{*}{45} & 1 & 1 & 1 & 2 \\
\hline & 2 & 1 & - & 1 \\
\hline & 3 & 1 & 1 & 2 \\
\hline & 4 & 1 & - & 1 \\
\hline & 5 & 1 & - & 1 \\
\hline & 6 & 1 & 1 & 2 \\
\hline \multirow{3}{*}{47} & 3 & 1 & - & 1 \\
\hline & 4 & 1 & 1 & 2 \\
\hline & 5 & 1 & 1 & 2 \\
\hline 48 & 3 & - & 1 & 1 \\
\hline 49 & 1 & 1 & - & 1 \\
\hline \multicolumn{2}{|c|}{ Grand Total } & 20 & 10 & 30 \\
\hline
\end{tabular}

\section{BX1794}

41BX1794 is located in the eastern portion of the project area and consists of a main structure, barn and stock tanks. A 2005 aerial photograph of the site indicated that four additional 


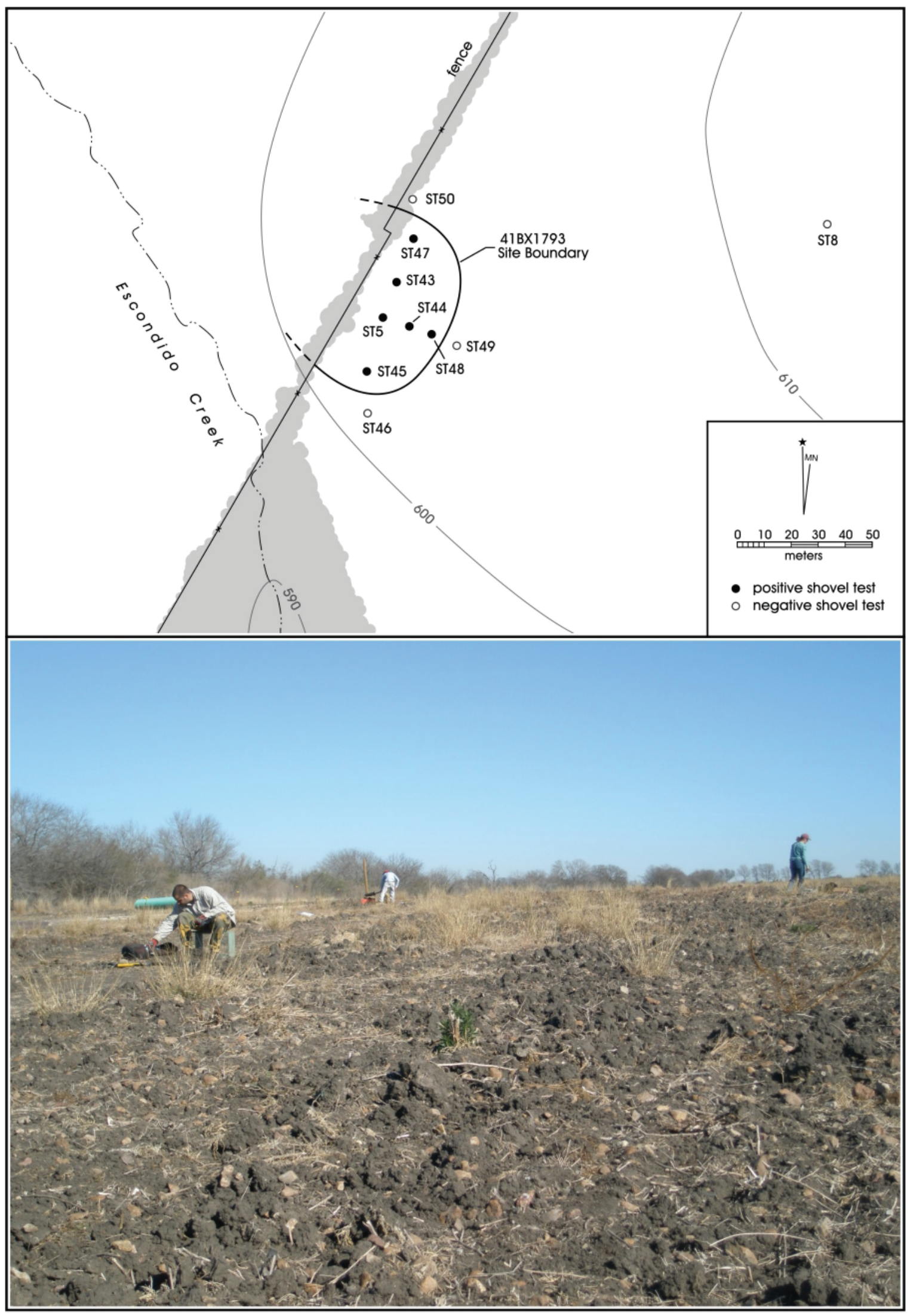

Figure 4-5. Site map and photograph of $41 B X 1793$. 
outbuildings were once part of the site but they were no longer present at the time of the archaeological survey (Figure 4-6). A construction trailer and a graded gravel covered area is in the portions of the site where the additional buildings would have been located (Figure 4-7). The site is sparsely vegetated.

The frame main structure is approximately $20 \mathrm{~m}-\mathrm{x}-12 \mathrm{~m}$ and is located just south of the area disturbed by leveling and the construction trailer. The northern portion of the structure has a porch just off the kitchen (Figure 4-8). The northern portion of the structure is wider than the southern portion making a t-shape (Figure 4-9). Figures 4-10 and 4-11 show the east side of the main structure which is wider to the north and the southern portion has has three windows and two entrances along a concrete porch. The barn associated with the site is located 45 meters southeast of the main structure that is wood framed and covered with corrugated metal. The two stock tanks are southeast of the barn. The site measures $9,897 \mathrm{~m}^{2}$.

Two shovel tests were excavated east and south of the main structure (ST 63 and 64). Shovel tests (Table 4-4) produced historic ceramics $(n=1)$, glass shards $(n=7)$, metal $(n=1)$ and debitage $(n=1)$. The majority of artifacts were recovered from Levels 1 and 2 of shovel tests. The historic artifacts and structures present at 41BX1794 date to the early to mid $20^{\text {th }}$ century. The single piece of debitage was classified as an isolated find.

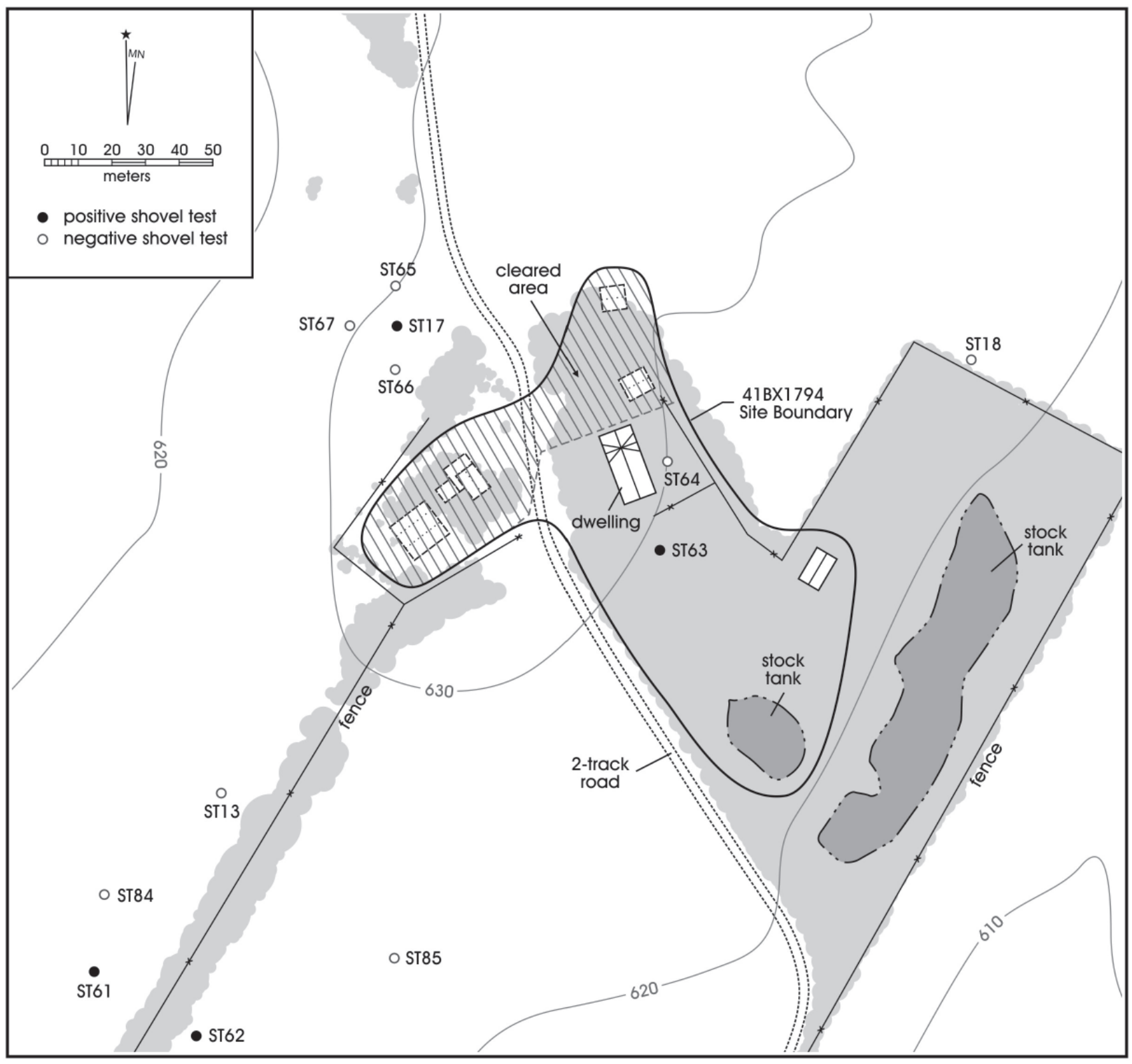

Figure 4-6. Site map of $41 B X 1794$. 


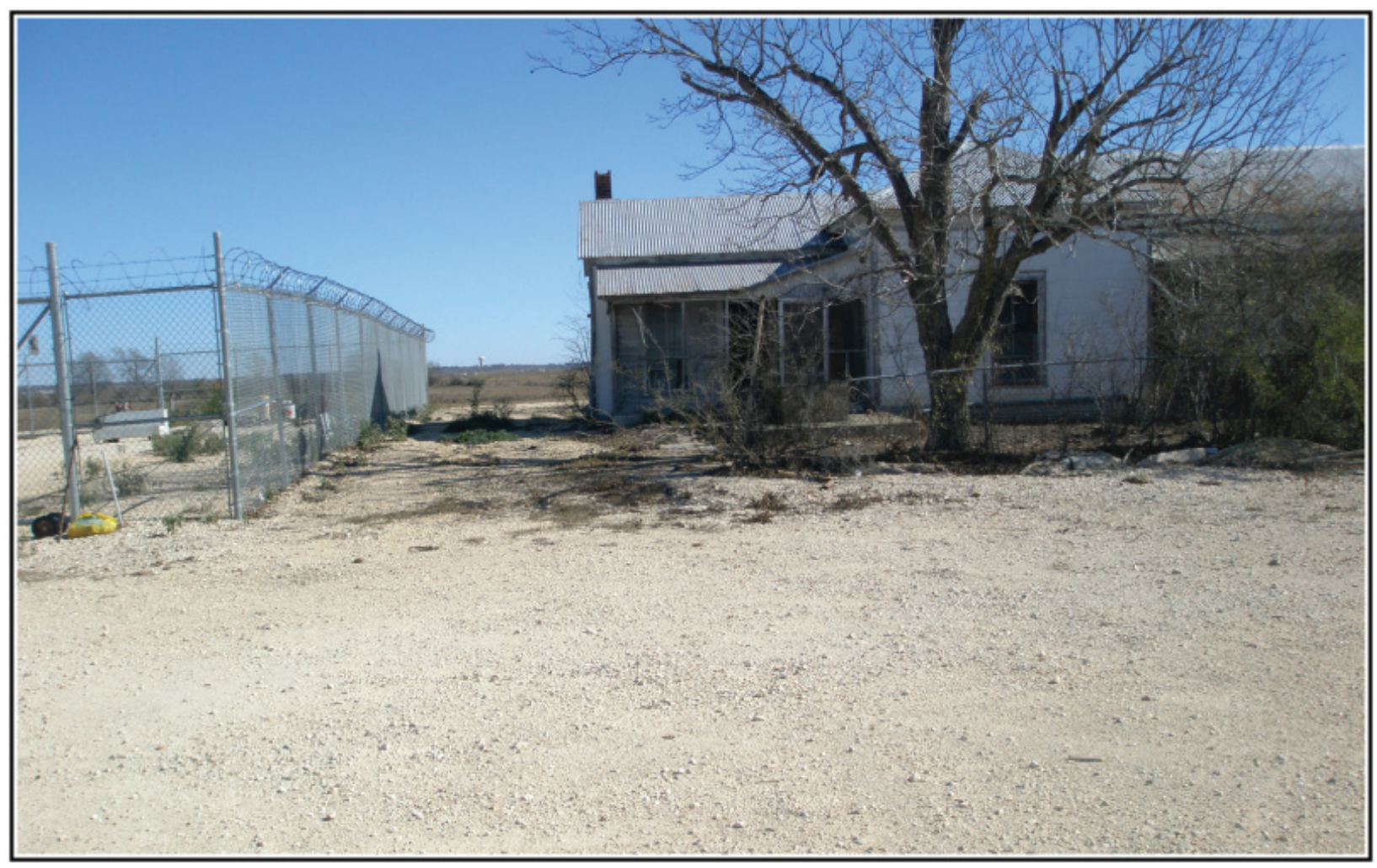

Figure 4-7. The east façade of the main structure at 41BX1794 and fenced construction area (on left).

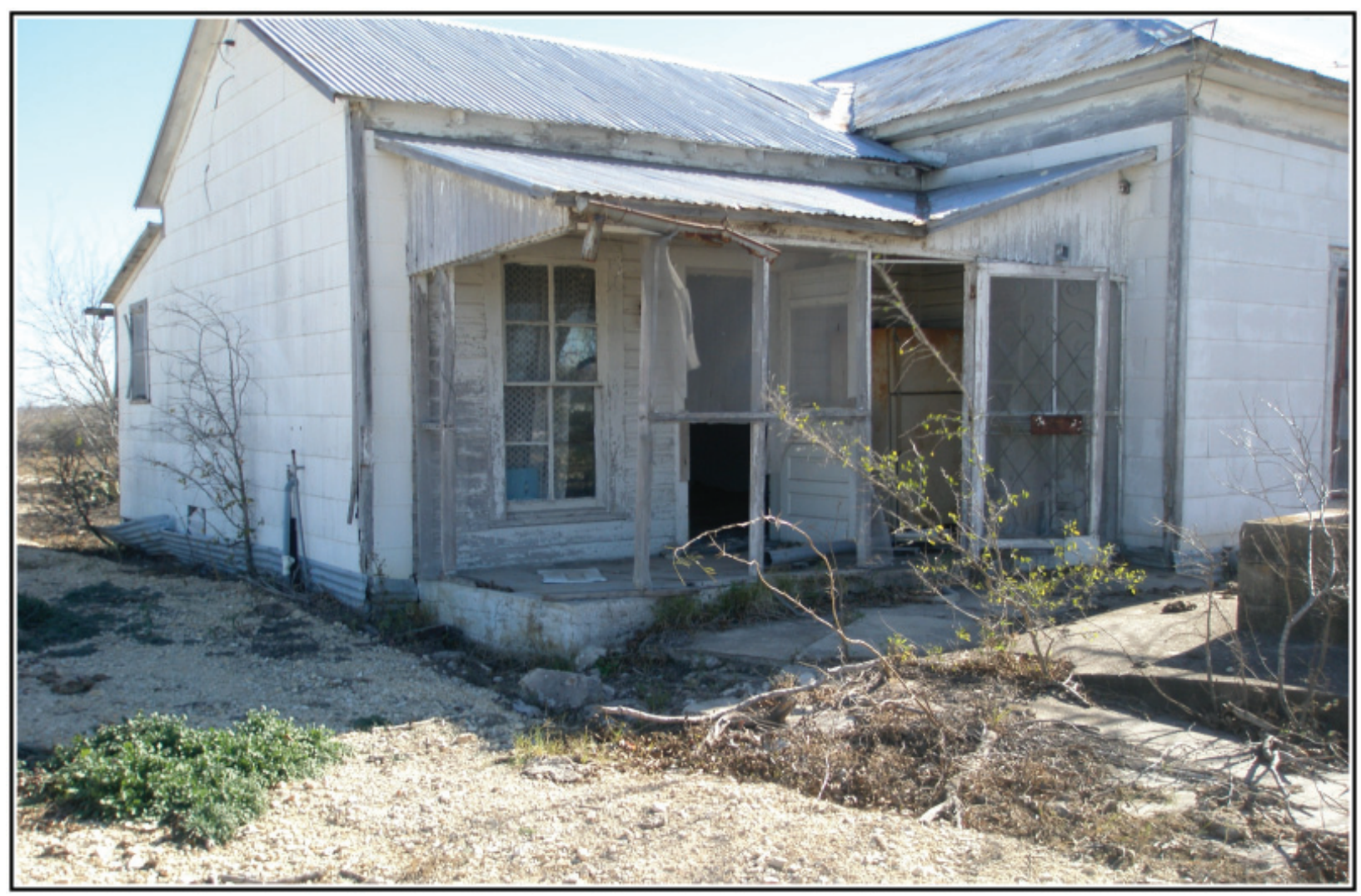

Figure 4-8. Remnants of a screened in porch off the kitchen on the north-western side of the structure. 


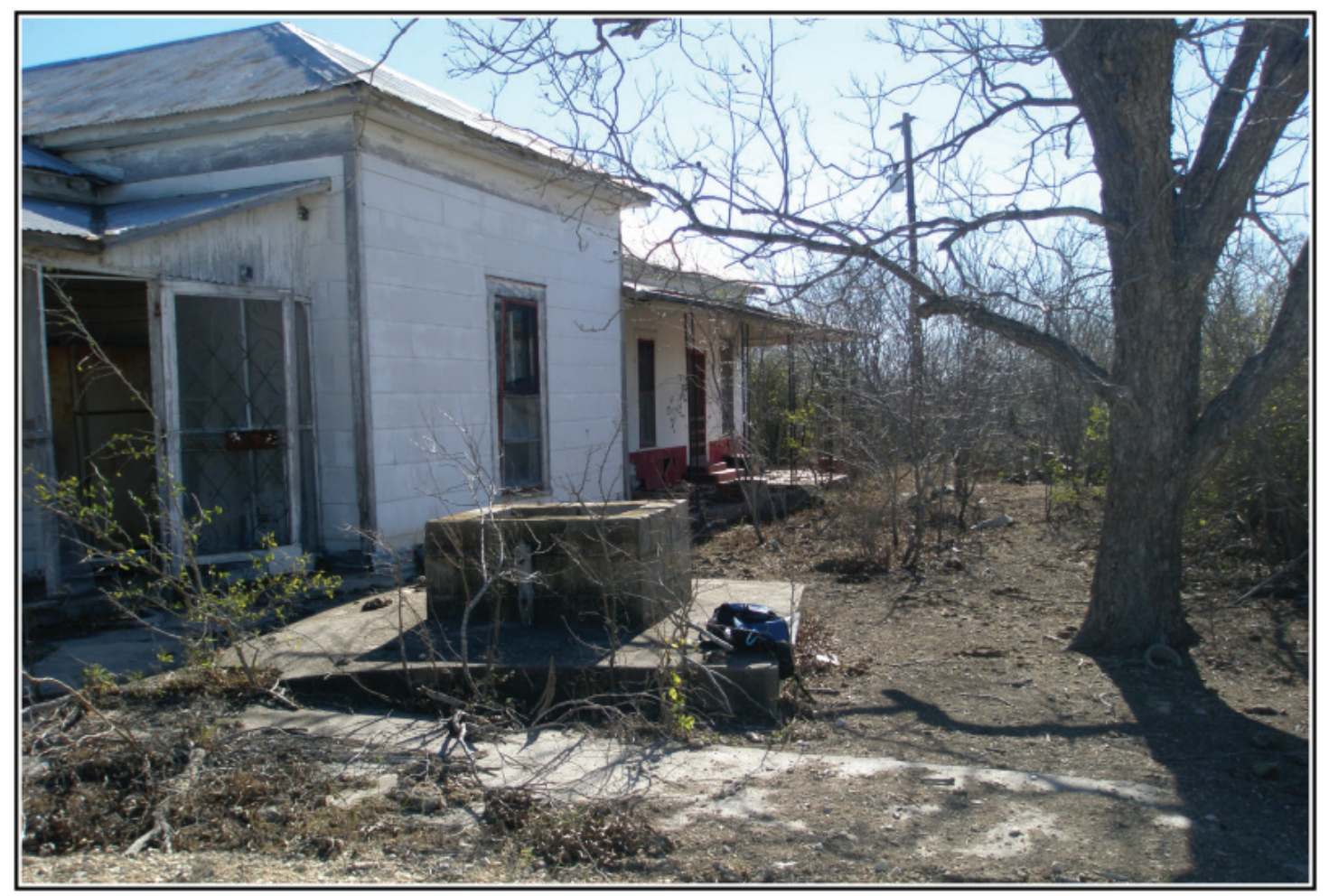

Figure 4-9. The western façade of the structure.

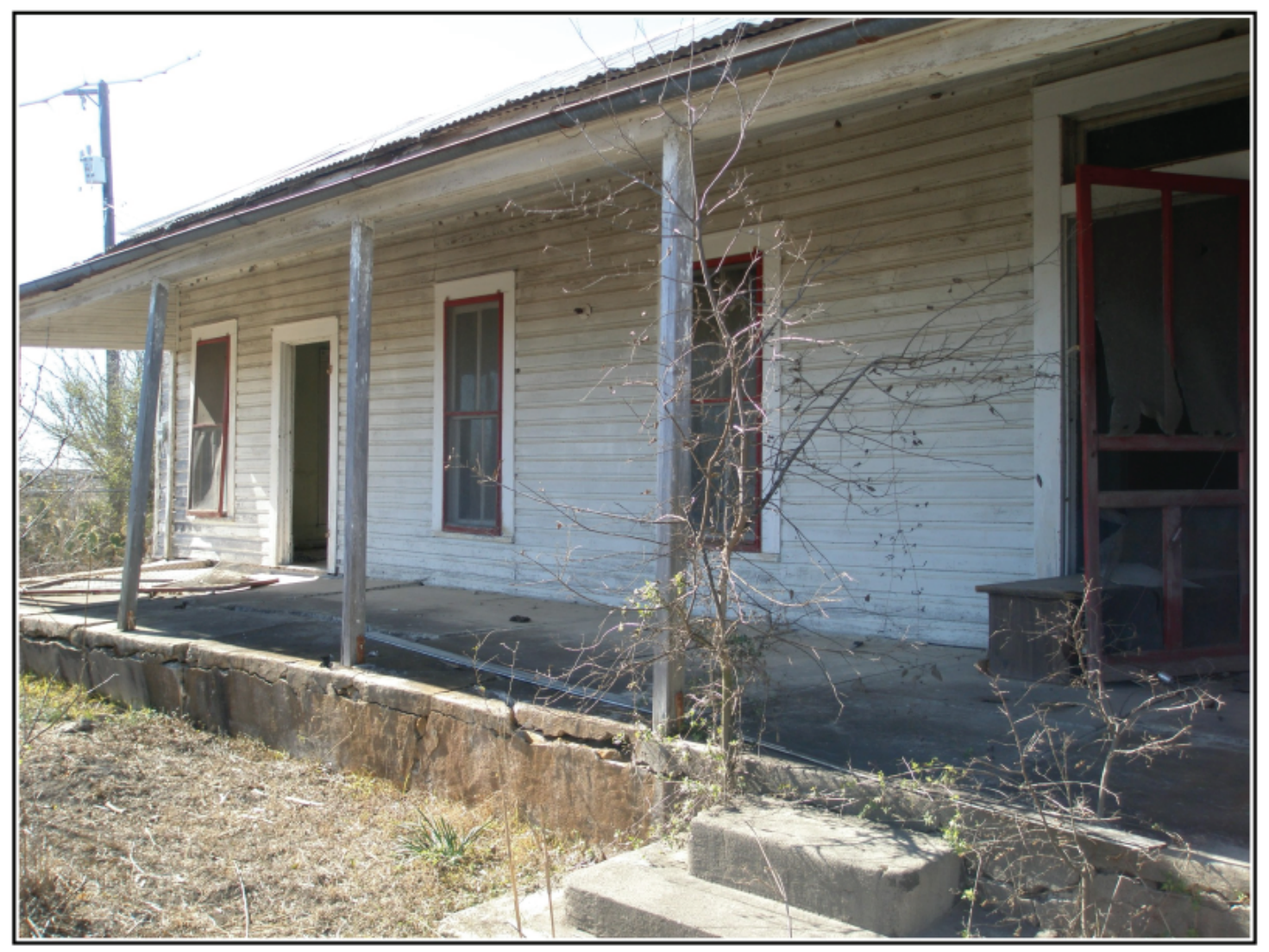

Figure 4-10. The east façade of the main structure at 41BX1794. 


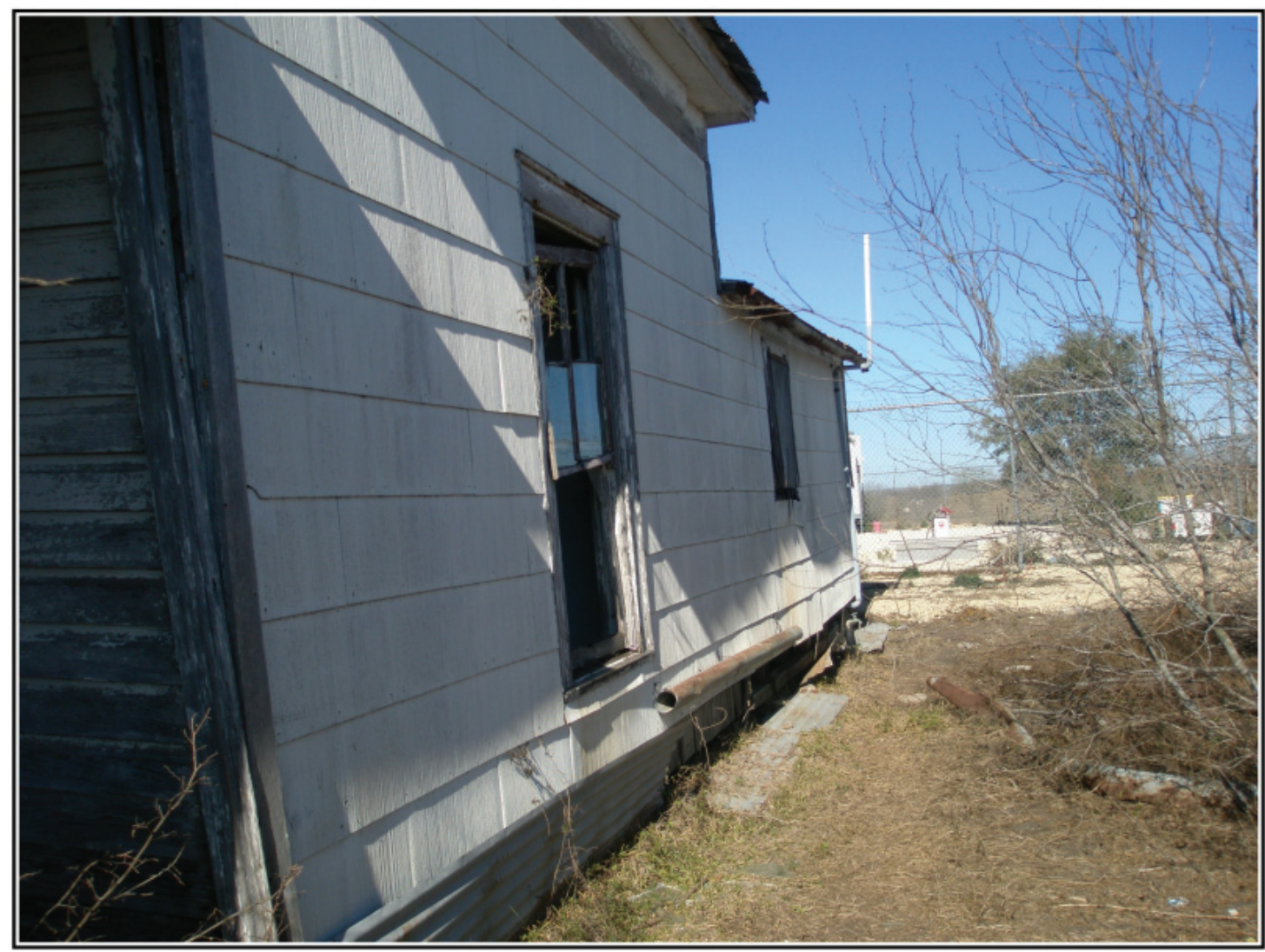

Figure 4-11. The north eastern portion of the structure.

Table 4-4. Artifacts Recovered from 41BX1794

\begin{tabular}{|c|c|c|c|c|c|c|}
\hline $\begin{array}{c}\text { Shovel } \\
\text { Tests }\end{array}$ & Level & Ceramics & Debitage & Glass & Metal & $\begin{array}{c}\text { Grand } \\
\text { Total }\end{array}$ \\
\hline \multirow{2}{*}{63} & 1 & - & 1 & 3 & 1 & 5 \\
\cline { 2 - 7 } & 2 & 1 & - & 1 & - & 2 \\
\hline 64 & 2 & - & - & 3 & 0 & 3 \\
\hline \multicolumn{2}{|c|}{ Grand Total } & 1 & 1 & 7 & 1 & 10 \\
\hline
\end{tabular}

A deed search of the project area indicates that the property on which 41BX1794 is located belonged to the Behren family from 1905 (BCDR 229:35) until the around 1965. No mention of the structures was noted in the deed records. A 1903 USGS topographic map of San Antonio, Texas does not indicate structures on the APE that could represent 41BX1794. The Bexar County Appraisal District (BCAD 2009) dates the residence to 1920 . Based on the deed search and historic materials the farmstead was built and inhabited after 1903 .

\section{BX1795}

This site was located in the northwest portion of the APE (Figure 4-12). It is a historic farmstead with a main structure and 14 associated outbuildings. The main structure is a wooden frame house that dates to the early-20th to mid$20^{\text {th }}$ century and measures $20 \mathrm{~m}-\mathrm{x}-10 \mathrm{~m}$. The site measures $16,314 \mathrm{~m}^{2}$. Figures 4-13 and 4-14 show a southern view of the house along with the garage and outhouse that is located just southwest of the house. The outbuildings consist of barns, sheds and pens (Figure 4-15). Two shovel tests were excavated on the site, west and south of the main structure but were devoid of cultural material. Items observed in the house includes a brass compass (Figure 4-16) that was still its box dated 1942 .

As in the case with $41 \mathrm{BX} 1794$, the property on which 41BX1794 is located belonged to the Behren family from 1905 (BCDR 229:35) until the around 1965. There is no mention of the structures in the deed records. The review of a 1903 topographic map of San Antonio Texas does not indicate any structures in the portion of the APE where 41BX1795 was recorded. The Bexar County Appraisal District (BCAD 2009) dates the residence to 1925. Based on the information obtained from the deed records, appraisal district and historic quadrangle maps the site dates to the early- $20^{\text {th }}$ to mid $20^{\text {th }}$ century. 


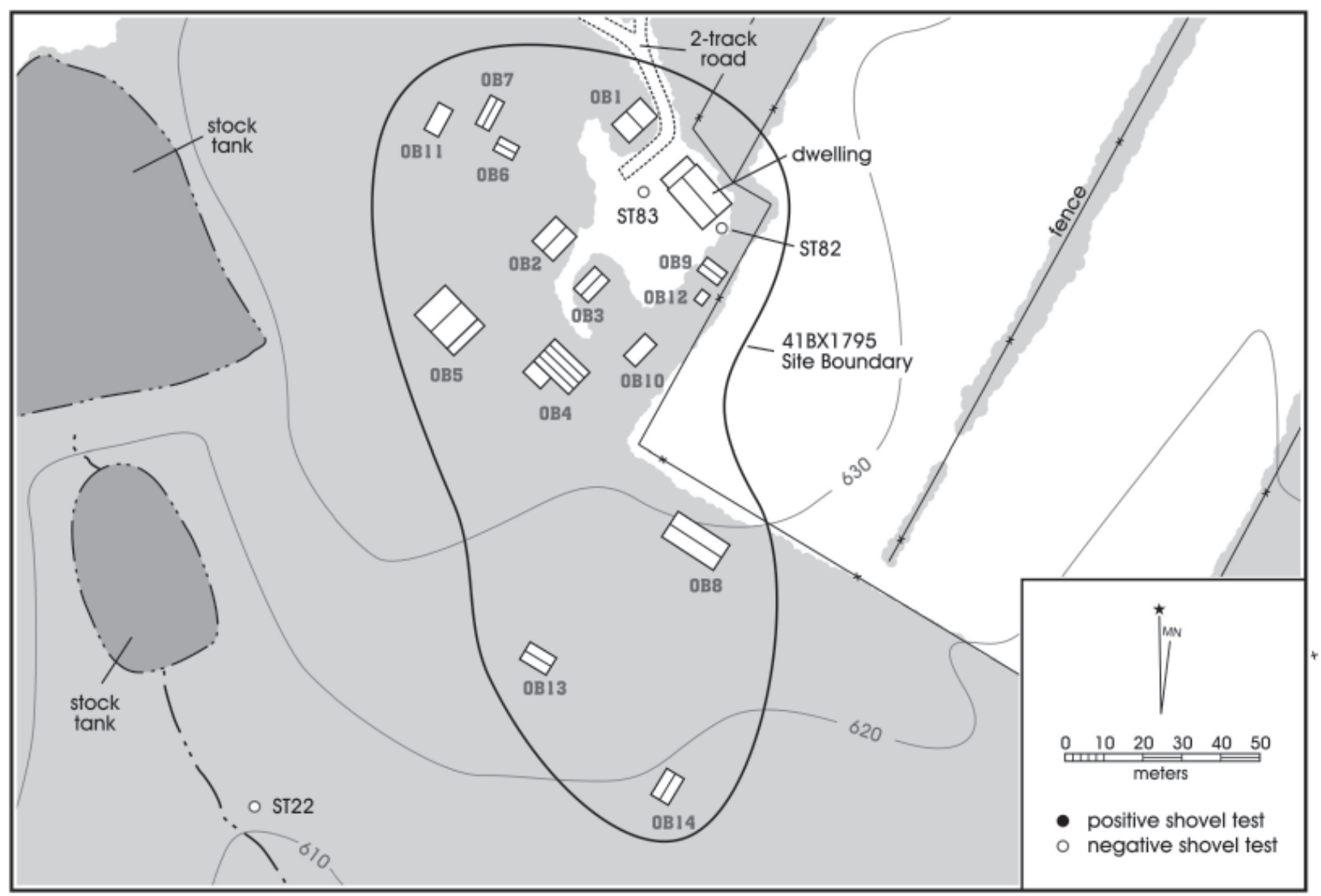

Figure 4-12. Site map of $41 B X 1795$.

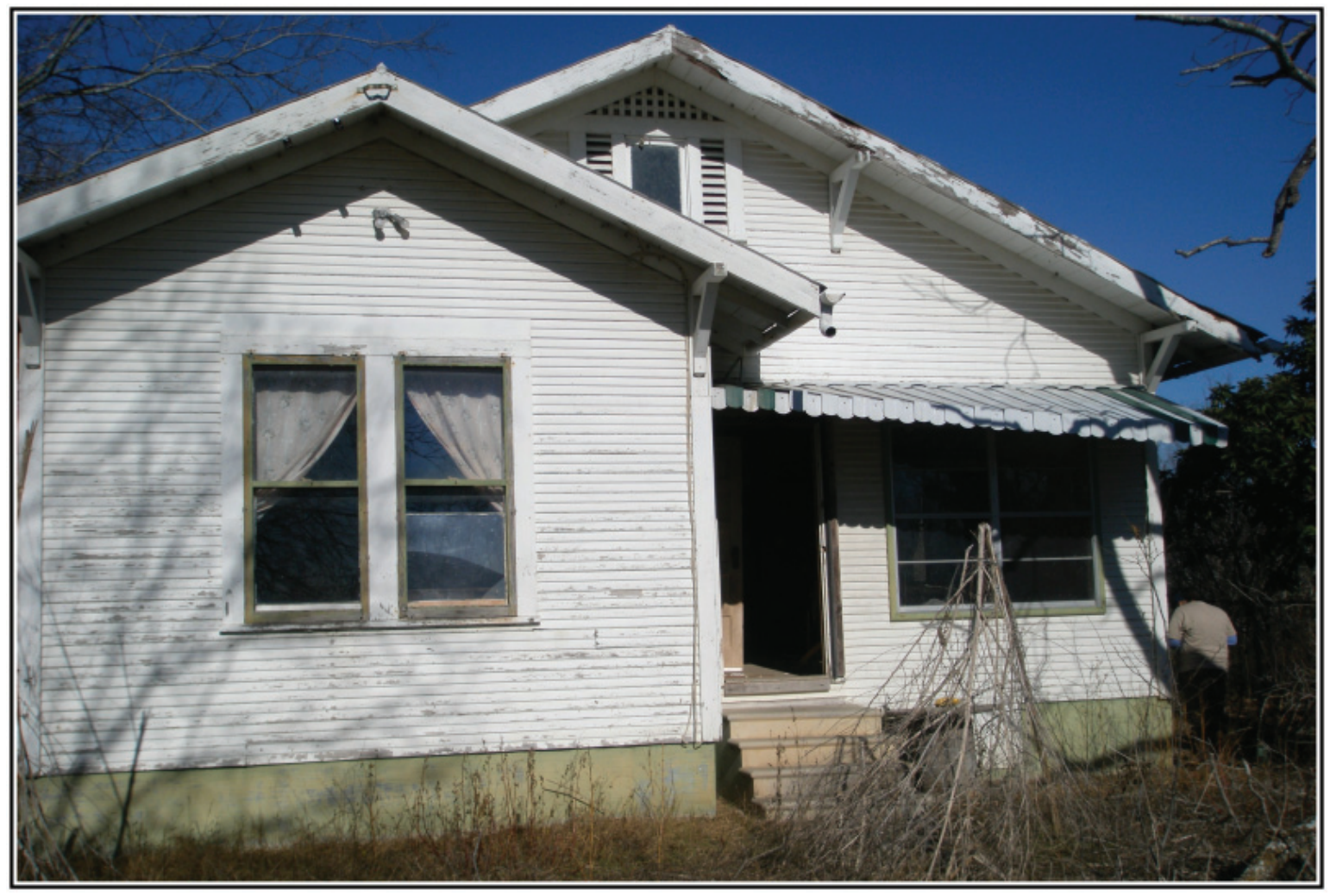

Figure 4-13. The south façade of the main structure at 41BX1795. 


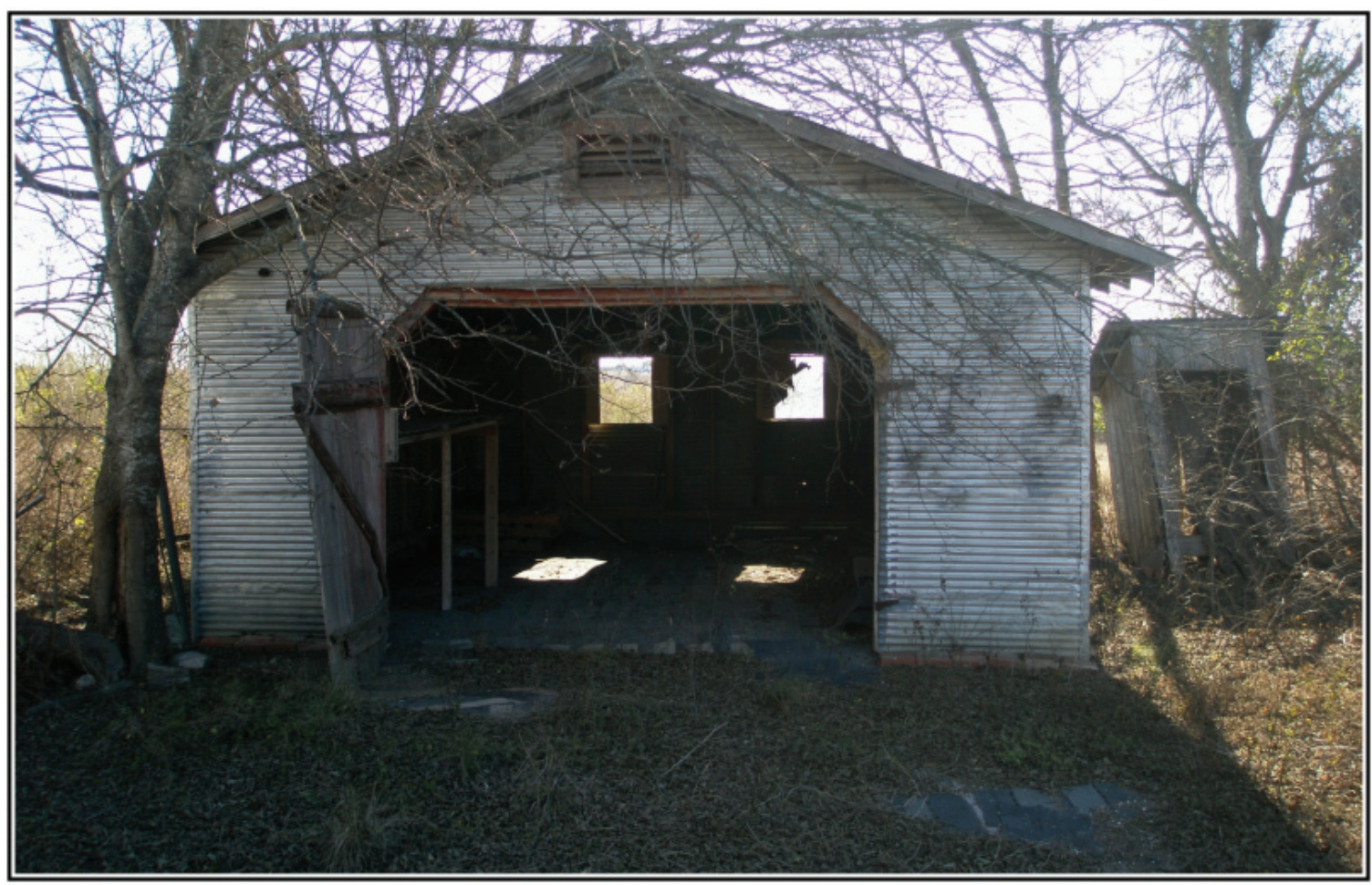

Figure 4-14. Outbuilding 9 (garage) and Outbuilding 12 (outhouse) at 41 BX1795 (facing east).
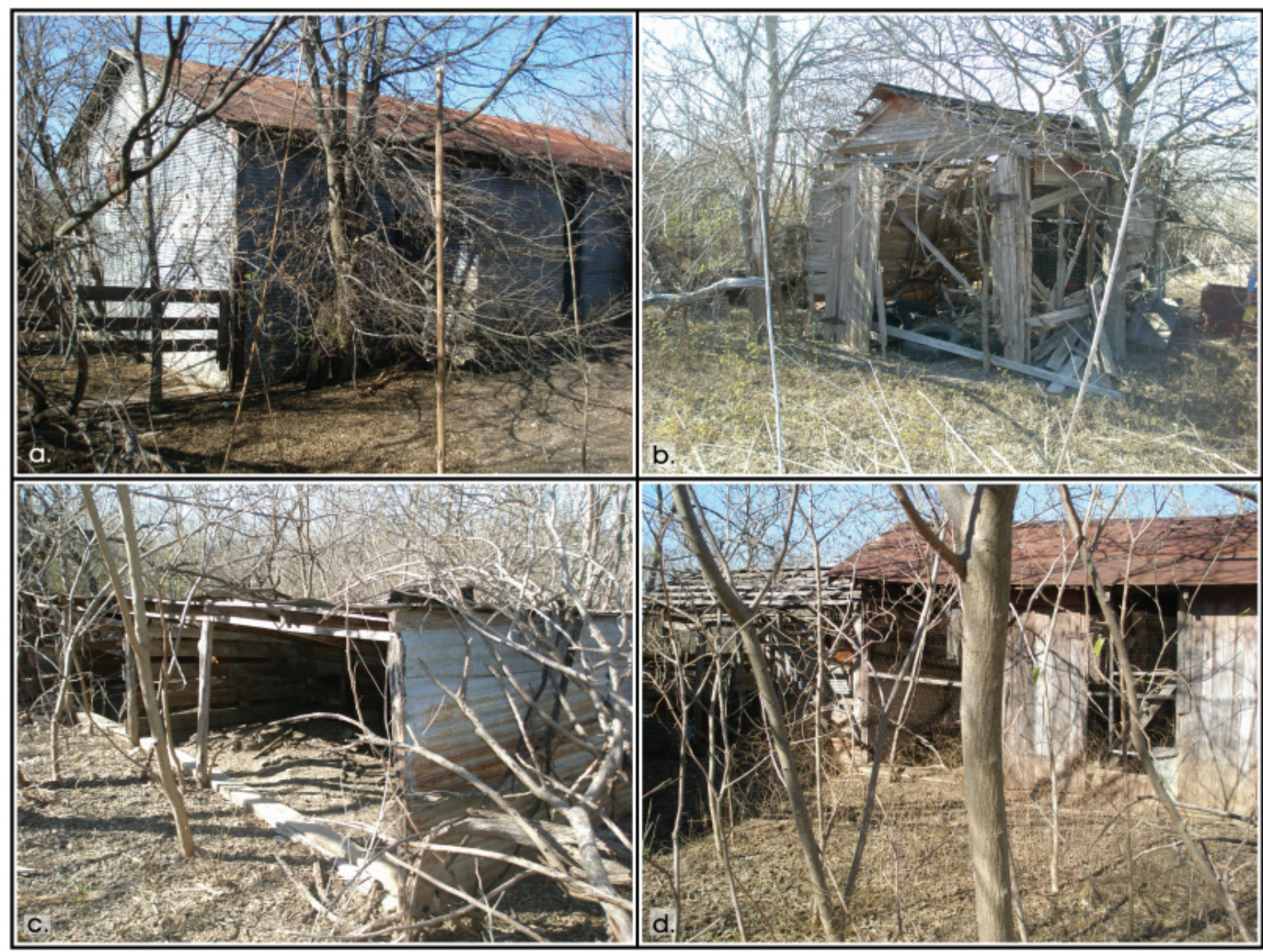

Figure 4-15. Outbuildings at 41BX1795: a) barn b) shed and c-d) pens. 


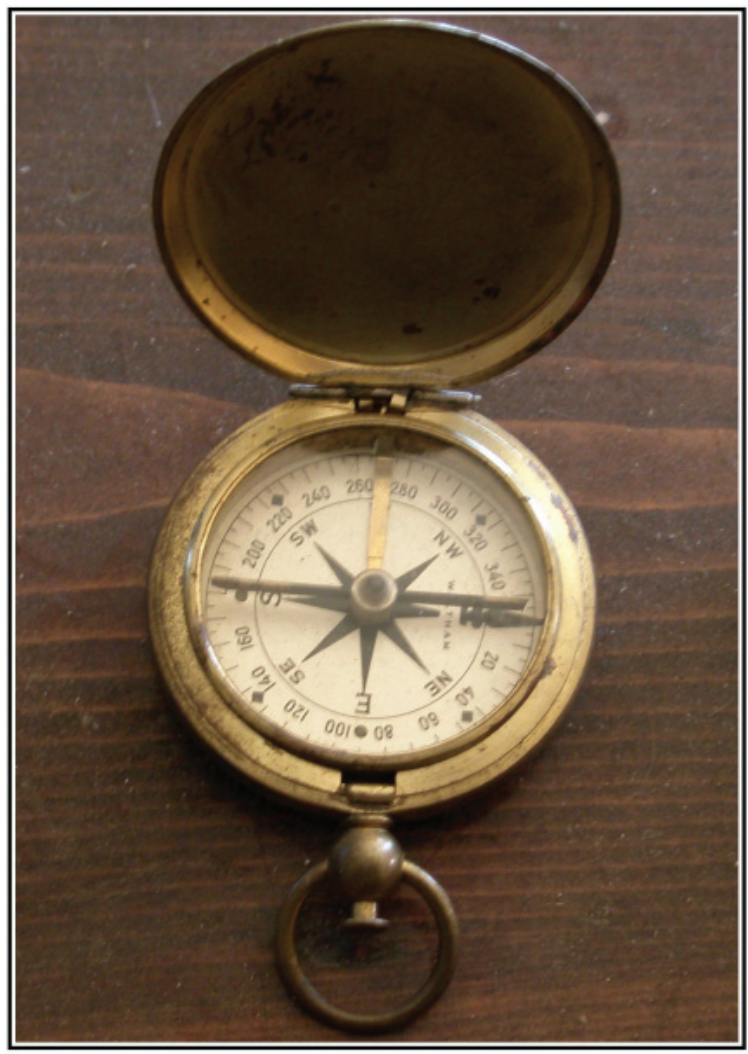

Figure 4-16. Brass compass dated 1942 observed in the main structure of $41 B X 1795$.
CAR does not recommend the site for listing on the NRHP or for formal designation as a SAL. Further work is not recommended on the site.

\section{Summary}

During the archaeological survey of the 328 acres that will be impacted by the Paloma Subdivision, 85 shovel tests were excavated and four sites were identified and recorded. A majority of the APE has been disturbed by plowing that includes disturbance to prehistoric sites $41 \mathrm{BX} 1792$ and 41BX1793. A scatter of surface and subsurface cultural materials was present at prehistoric site 41BX1792 that consisted of burned rock, debitage, bifaces and a stem of a Late Prehistoric Edwards projectile point. A low density of debitage and burned rock was encountered at 41BX1793.

Historic sites 41BX1794 and 41BX1795 date to the early-20 $0^{\text {th }}$ to mid $20^{\text {th }}$ century and exhibit standing structures. Shovel tests excavated at both sites produced minimal cultural material. Portions of 41BX1794 have been disturbed by clearing associated with construction preparation.

Five isolated finds were encountered that included subsurface materials in shovel tests and surface finds. Further work is not recommended in the APE. 


\section{Chapter 5: Conclusions and Recommendations}

In January 2009 the Center for Archaeological Research conducted an archaeological survey for the Paloma Subdivision in eastern Bexar County, Texas. The archaeological work completed by CAR was contracted by I-10 Investments LTD. During the course of the survey, the APE, consisting of 328 acres, was subjected to 85 shovel tests. As a result, four archaeological sites (41BX1792, 41BX1793, 41BX1794 and 41BX1795) were identified and recorded by the CAR field crew. In addition to the four recorded sites, five isolated finds were also noted.

41BX1792 was identified as a prehistoric site with a scatter of burned rock, lithic debitage and tools visible on surface and recovered from shovel tests. The majority of site has been disturbed by plowing and materials are concentrated in the 30 to $40 \mathrm{~cm}$ of plow zone. Due to the lack of intact materials and disturbance, CAR does not recommend the site for listing to the NRHP or formal SAL designation. Further work is not recommended on the site.

A second prehistoric site, 41BX1793, was recorded within the APE. Burned rock and lithic debitage was recovered from shovel tests excavated on the site. As the case with 41BX1792, this site also has been disturbed by plowing and CAR does not recommend the site for listing to the NRHP or formal SAL designation. Further work is not recommended on the site.

Two historic farmstead sites that date to the early- to mid- $20^{\text {th }}$ century were also recorded during the Paloma archaeological survey. Site 41BX1794 consists of a residence, an associated barn and stock tanks. Additional structures originally part of this site were removed before the archaeological survey. Shovel tests excavated on the site produced only a few artifacts. The site complex is heavily damaged. Four structures related to the site have been demolished prior to the survey. The exterior of the residence is covered with synthetic shingles and it has a corrugated metal roof. The concrete porch, on the western side of the house, is severely cracked and the wooden posts supporting the porch roof are in poor condition. The northern portion of the house appears to be early as it has a pier and beam foundation while the southern portion of the structure has a concrete slab foundation indicating it is a later addition. The interior floors in the southern portion of the structure are covered in sheet linoleum that is in poor condition. While the kitchen in the northern portion of the structure has tiles, they are most likely asbestos.

The original complex was build in 1920, and it is an example of an early twentieth century homestead. However, given the destruction of all but one of the out buildings, the two phases of construction exhibited by the remaining main house, and the dilapidated condition of the architectural elements, we do not believe that it has sufficient remaining architectural integrity to warrant additional work. Therefore, CAR does not recommend the site's listing to the NRHP or as an SAL. Further work is not recommended on the site.

Site 41BX1795 is the second historic site recorded during CAR's survey of the APE. It consists of a residence and 14 outbuildings that include barns, sheds and animal pens. Shovel tests excavated on the site were void of cultural materials. The structures lacked integrity and the site is not recommended for listing to the NRHP or as an SAL. Further work is not recommended on the site.

The San Antonio Historic Preservation Office (HPO) concurred with the recommendations and further work is not recommended in the APE and the proposed construction associated with the Paloma Subdivision project can proceed as planned. 



\section{References Cited}

Bauer, J.

1974 The Mexican War, 1846-1848. Macmillan, New York.

Bement, L.C.

1989 Excavations at 41BP19: The Kennedy Bluffs Site, Bastrop County, Texas. Texas Archaeological Research Laboratory, The University of Texas at Austin. Contract Reports in Archaeology, Report No. 5, Highway Design Division, Texas State Department of Highways and Public Transportation, Austin.

Bexar County Appraisal District (BCAD)

2008 http://www.bcad.org/, Accessed January 29, 2008

Bexar County Deed Records (BCDR)

2008 http://www.countyclerk.bexar.landata.com/, Accessed January 29, 2008.

Black, S.L. and D.G. Creel

1997 The Central Texas Burned Rock Midden Reconsidered. In Hot Rock Cooking on the Greater Edwards Plateau: Four Burned Rock Midden Sites in West Central Texas, by Steve Black, Linda W. Ellis, Darrell G. Creel, and Glenn T. Goode, pp.269-305. Studies in Archeology 2. Texas Archeological Research Laboratory, The University of Texas at Austin.

Bomar, G.

1999 Texas Weather. The University of Texas Press, Austin.

Buckley, E.C.

1991 The Aguayo Expedition into Texas and Louisiana, 1719-1722. Quarterly of the Texas State Historical Association $\mathrm{XV}(1): 1-65$

Buerkle, R.C.

1976 The Continuing Military Presence. In San Antonio in the $18^{\text {th }}$ Century. San Antonio Bicentennial Heritage Committee.

Chipman, D.E.

1992 Spanish Texas, 1519-1821. University of Texas Press, Austin.

Collins, M.B.

1995 Forty Years of Archeology in Texas. Bulletin of the Texas Archeological Society 66:361-400.

Cox, I.W.

2005 Appendix D: History of the "Priest's House" on Military Plaza. In Test Excavations and Monitoring at 41BX1598: A Multicomponent Historic Site in Bexar County, Texas. Archaeological Report, No. 360. Center for Archaeological Research, The University of Texas at San Antonio.

Fox, A.A.

1997 Test Excavations at the Spanish Governor's Palace, San Antonio, Texas. Archaeological Survey Report, No. 259. The Center for Archaeological Research, The University of Texas at San Antonio. 
Fox, A.A., M. Renner, and R.J. Hard

1997 Archaeology at the Alamodome: Investigations of a San Antonio Neighborhood in Transition, Volume III: Artifacts and Special Studies. Archaeological Survey Report, No. 238. Center for Archaeological Research, The University of Texas at San Antonio.

Fox, A.A. and I.W. Cox

2000 Archaeological Monitoring for Exterior Lighting and Test Excavations at Mission San Juan Capistrano, Bexar County, Texas. Letter Report, No. 131. Center for Archaeological Research, The University of Texas at San Antonio.

Hall, G.D., T.R. Hester, and S.L. Black

1986 The Prehistoric Sites at Choke Canyon Reservoir, Southern Texas: Results of the Phase II Archaeological Investigations. Choke Canyon Series, No. 10. Center for Archaeological Research, The University of Texas at San Antonio.

Hester, T.R.

1995 The Prehistory of South Texas. Bulletin of the Texas Archeological Society 66:427-459.

Hoffman, F.L. (translator)

1937 Diary of the Alarcón Expedition into Texas, 1718-1719. Quivira Society Publications Volume 45:39.

Inman, B.J., T.C. Hill, Jr., and T.R. Hester

1998 Archeological Investigations at the Tortugas Flat Site, 41ZV155, Southern Texas. Bulletin of Texas Archeological Society 69:11-33.

Mauldin, R.P., D.L. Nickels, and C.J. Broehm

2003 Archaeological Testing to Determine the National Register Eligibility Status of 18 Prehistoric Sites on Camp Bowie, Brown County, Texas. Archaeological Survey Report, No. 334. Center for Archaeological Research, The University of Texas at San Antonio.

Mauldin, R.P., B.K. Moses, R.D. Greaves, S.A. Tomka, J.P. Dering and J.D. Weston 2004 Archeological Survey and Testing of Selected Prehistoric Sites along FM 48, Zavala County, Texas. Archaeological Survey Report, No. 352, Center for Archaeological Research, The University of Texas at San Antonio, and Archeological Studies Program, Report No. 67, Environmental Affairs Division, Texas Department of Transportation, Austin.

Mauldin, R.P., J.L. Thompson, and L. Kemp 2006 Bison, Bowls, and Bunnies. Paper presented at the $82^{\text {nd }}$ Society for American Archaeology Annual Meeting, Austin.

McKinney, W.W.

1981 Early Holocene Adaptations in Central and Southern Texas: The Problem of the Paleoindian-Archaic Transition. Bulletin of the Texas Archaeological Society 52:91-120.

Meltzer, D.J. and M.R. Bever

1995 Paleoindians of Texas: An Update on the Texas Clovis Fluted Point Survey. Bulletin of the Texas Archeological Society $66: 47-81$.

Nickels, D.L. and R.P. Mauldin

2001 The Project Environment. In An Archaeological Survey of Twin Buttes Reservoir, Tom Green County, Texas, edited by R. Mauldin and D.L. Nickels, pp 25-38. Archaeological Survey Report, No. 300, Center for Archaeological Research, The University of Texas at San Antonio. 
Perttula, T.K., M.R. Miller, R.A. Ricklis, D.J. Prikryl, and C. Lintz 1995 Prehistoric and Historic Aboriginal Ceramics in Texas. Bulletin of the Texas Archeological Society 66:175-235.

Ricklis, R.A.

1992 The Spread of the Late Prehistoric Bison Hunting Complex: Evidence from the South-Central Coastal Prairie of Texas. Plains Anthropologist 37(140):261-273.

Story, D.A.

1985 Adaptive Strategies of Archaic Cultures of the West Gulf Coastal Plain. In Prehistoric Food Production in North America, edited by R.I. Ford, pp. 19-56. Anthropological Papers No. 75. Museum of Anthropology, University of Michigan, Ann Arbor.

Taylor, F.B., R.B. Hailey, and D.L. Richmond

1991 Soil Survey of Bexar County, Texas. United States Department of Agriculture, Soil Conservation Service. Washington, D.C.

Texas Historical Commission (THC)

2009 Texas Archaeological Sites Atlas, http://www.nueces.thc.state.tx.us. Accessed January 29, 2009.

Turner, S.E., and T.R. Hester

1993 Stone Artifacts of Texas Indians. Second Edition. Texas Monthly and Gulf Publishing Company, Houston.

Wade, $\mathrm{M}$.

2003 The Native Americans of the Texas Edwards Plateau, 1582-1799. The University of Texas Press, Austin.

Wallace, E.

1965 Texas in Turmoil: The Saga of Texas, 1849-1875. Steck-Vaughn, Austin

Weddle, R.S.

1968 San Juan Bautista: Gateway to Spanish Texas. The University of Texas Press, Austin. 
